\title{
La experiencia estética como acontecimiento que produce lo político
}

En este capítulo se pretende comprender cómo la experiencia estética que plantean estos grupos determina sus prácticas y cómo contribuyen a la construcción de un imaginario de lo político. Para este fin, se proponen tres momentos: el inicial, referido a la experiencia estética y su importancia en la configuración del acontecimiento a través de las modalidades propuestas por los jóvenes, a saber: el teatro, el juego y el audiovisual; seguidamente se caracteriza a profundidad cada experiencia con sus particularidades, atendiendo a la implicación directa entre experiencia estética y las prácticas que adelantan estos agentes; finalmente, se concluye con la relación entre estos elementos y el imaginario de lo político propuesto o producido en el accionar de estos grupos.

\section{Sobre la experiencia estética y su potencia de acontecimiento}

Para entender la experiencia estética, es necesario atender a la relación directa entre el sujeto y el conocimiento. "Así, conceptos como sensibilidad, sensación, percepción y conocimiento se articulan como manifestación de la experiencia, gracias a la cual se advierte y se aprehende el mundo. La experiencia involucra necesariamente la pregunta por 
quién conoce y cómo se conoce" (Mier Garza, 2015); es decir, implica preguntarse cómo se produce el conocimiento en el sujeto, en este caso a través de la corporalidad, o sea, de la experiencia de sentir, vivir, percibir y operar en el mundo.

"Kant consolida la noción de experiencia como una presentación intuitiva de los datos del mundo, a través de la síntesis, pasar de las sensaciones a una síntesis, como una abstracción heterogénea, donde lo que yo siento con la silla lo sintetizo en el objeto llamado silla al que le atribuyo un concepto como construcción categorial" (Mier Garza, 2015). Pero esas formas de acceder a esa síntesis son diferentes cuando interviene el gusto o el placer, pues no es equivalente a la lógica causal. Kant se ocupó de comprender a profundidad este asunto, para reconocer las condiciones subjetivas del conocimiento. "Kant trata de concluir el problema diciendo que, puesto que el sentimiento es el sentimiento del libre juego de nuestras facultades de conocer, este sentimiento es, él mismo, un conocimiento, por lo que puede ser universalmente compartido" (Bayer, 1965, p. 206).

De esta manera, Kant vincula a lo bello con una razón teórica del juicio. Para ello se ocupa de desentrañar el fundamento de lo bello, indicando que el sentimiento de lo estético se vincula más con la idea de libertad que con los fenómenos mismos, dada su condición de desinterés o su independencia respecto de los sentidos y la necesidad.

Entre las cosas del universo que nos obligan a pensar algo diferente de la necesidad, se encuentra lo bello. Al estudiar a Kant, Schiller en un comienzo se muestra asombrado por este hecho: de ninguna manera puede hablarse de la objetividad de lo bello. Kant, al analizar lo bello y lo sublime nos dice que todo lo bello nos causa placer, pero un placer desinteresado; el placer puede ser universalmente compartido. "Es una especie de contradicción en sí: el placer tiene una "subjetividad subjetiva" (Mier Garza, 2014, s. p.). Toda afectividad es enteramente subjetiva. Es imposible resolver la antinomia del gusto en nombre de la razón.

Para Kant, el placer estético no se asemeja a los otros. La diferencia no es solo de grado, sino de naturaleza. Dos de nuestras facultades intelectuales, de costumbres divergentes, se muestran aquí de acuerdo: la imaginación y el entendimiento. Esta coincidencia 
inhabitual nos produce placer; y es ese placer basado en que sea desinteresado y no requiere ser una posesión material. No es un placer únicamente sensible sino intelectual. (Bayer, 1965, pp. 207 y 208)

De modo similar, Rancière destaca el concepto de experiencia estéti$c a$ en su vinculación con el juego, remontándose a los postulados de Schiller (retomando a Kant), quien afirmó que el juego se consolida como una expresión de lo imaginario, que escapa a la normativa y se configura como una constante interrogación sobre lo instituido, sobre la temporalidad y la pretensión de inmutabilidad de la subjetividad, y que afecta los modos de ser de los jugadores; así, configura para el francés un ejemplo concreto de producir una forma de división de lo sensible, que justamente puede entenderse como experiencia estética.

Esto es lo que quiere decir "estética": la propiedad de ser del arte en el régimen estético del arte ya no está dada por criterios de perfección técnica, sino por la asignación a una cierta forma de aprehensión sensible. La estatua es una "apariencia libre" es decir, una forma sensible heterogénea por contraposición a las formas ordinarias de la experiencia sensible. Aparece a través de una experiencia específica que suspende las conexiones ordinarias no solamente entre apariencia y realidad, sino también entre forma y materia, actividad y pasividad, entendimiento y sensibilidad.

Precisamente es esta forma nueva de división de lo sensible lo que Schiller resume con el término de "juego". Reducido a su definición escueta, el juego es una actividad que no tiene otro fin que ella misma, que no se propone adquirir ningún poder efectivo sobre las cosas y sobre las personas. Esta acepción tradicional del juego ha sido sistematizada por el análisis kantiano de la experiencia estética. Este se caracteriza efectivamente por una doble suspensión: una suspensión del poder cognitivo del entendimiento, determinando los datos sensibles de acuerdo con sus categorías; y una suspensión correlativa del poder de la sensibilidad imponiendo objetos de deseo. El "libre juego" de las facultades —intelectual y sensible - no es únicamente una actividad sin finalidad, es una 
actividad equivalente a la inactividad, a la pasividad. Para empezar, la "suspensión" que practica el jugador, co-relación a la experiencia ordinaria, es correlativa a otra suspensión, la suspensión de sus propios poderes, frente a la aparición de un bloque sensible heterogéneo, un bloque de "pasividad" pura. [...] ¿Y por qué esta suspensión funda al mismo tiempo un nuevo arte de vivir, una nueva forma de vida en común? Dicho de otro modo: ¿qué tiene de consustancial la "utopía" estética con la definición misma de la especificidad del arte en este régimen? La respuesta, en su formulación más general puede enunciarse así: porque ella define las cosas del arte en función de su pertenencia a un sensorium diferente del de la dominación. En el análisis kantiano, el libre juego y la apariencia libre suspenden el poder de la forma sobre la materia, de la inteligencia sobre la sensibilidad. (Rancière, 2005, pp. 24-25)

Con lo anterior, se puede entender que la experiencia estética es una modalidad del conocimiento empírico, que activa la construcción de sentido sobre el mundo a través de la expresión, y la configura como génesis de la significación, es decir, de atribuir significado y construir sentido como ejercicio interminable a partir de la expresión como fuerza que le da forma y la objetiva, y que responde a unos procesos diferentes a la causalidad y la necesidad.

La experiencia conlleva explicación y comprensión del mundo, así lo que significamos (el mundo) al expresarlo se objetiva, pues sin expresión no hay experiencia. Entonces, la expresión es condición de la experiencia estética y se entiende abiertamente que la experiencia es con otro, lo que produce significación; de esta manera, el mundo se da como objeto de sentido, pues la experiencia y la historia se constituyen en la intersubjetividad. La experiencia estética es expresión en sí misma, y da lugar a un vínculo con los otros y así la hace significativa.

Asimismo, la experiencia estética se revela como un hacer, que implica un ejercicio de comprensión del entorno, que escapa a todo ámbito de lo conceptual, y dada su relación directa con el ámbito de lo sensorial produce un modo de mirar, un ejercicio de explicación particular, pero también un modo de hacer, de construir significación. Así las cosas, tiene un vínculo muy estrecho con la creación. 
La experiencia estética no se orienta a la producción de objetos bellos o al arte propiamente dicho, sino que es un hacer complejo que implica un momento de composición o de creación; pero esa creación no se puede entender como creación pura, sino que es fruto de un ejercicio de reflexión y recreación, en este caso, colectiva, que se nutre de los intereses individuales o grupales en los cuales se produce, en función de su pertenencia histórica y territorial; una síntesis de muchas facetas e historias que inciden en el ejercicio de creación.

La interrogación por la creación es la pregunta misma por la experiencia estética, orientada a la creación de sí mismo (subjetividades), la creación del otro, desde el otro (identidades), la creación de mundos de significación (sentidos) a través de la creación de objetos (prácticas o experiencias inéditas).

Así, la experiencia estética que proponen estos jóvenes en sus acciones requiere un ejercicio de "aprehensión sobre su propia singularidad”, como señala Mier Garza (2015); es decir, responde a un proceso de síntesis y recreación particular que denota una identidad grupal o particular, que se produce en la combinación contingente de intereses y unos momentos específicos de acción, que le confieren un carácter inédito, ubicada histórica y territorialmente, y que propone un régimen de significación con una intencionalidad explícita en correspondencia con la construcción de sentidos que amplían los límites de significación instituidos.

La experiencia estética es también potencia creadora de sentidos o ámbitos de enunciación, que se presenta como una "capacidad de ser" que aún no es, pero que se encuentra contenida como fuerza o tensión implícita en su esencia, y que si las circunstancias adecuadas para el desarrollo de esa capacidad llegan a realizarse, es posible desatar esa tensión contenida en una obra, en una sesión de juego o en un corto audiovisual. De esta manera, se producirían en este caso nuevas relaciones con lo bello, con lo deseable, con la capacidad de asombro al develar otras formas de interrelación con objetos, agentes, lenguajes, significados y sensaciones.

Además de lo anterior, la potencia de la experiencia estética reside también en el poder que tiene esa obra, ese juego o ese audiovisual de producir un cambio en la subjetividad del público y los actores, de los 
participantes del juego o de los espectadores y realizadores del audiovisual; pero también se daría un cambio en la construcción de sentido sobre la realidad retratada, frente al territorio compartido o sobre los imaginarios que definen los límites de lo social.

De esta forma, en la experiencia estética reside una apertura o despliegue de potencia contingente, que se inserta en la cotidianidad compartida con los otros, lo que la hace inédita y socialmente productiva; "es la generación de ámbitos o espacios que, aunque se inscriban en el marco de lo instituido, están compuestos por una temporalidad, significación y ritualidad diferente a la habitual, lo que la hace particularmente única o excepcional" (Mier Garza, 2014, s. p.).

Una de las posibilidades que produce la experiencia estética tiene que ver con la generación de comunidad o vínculo que anida en su esencia, por el componente de creación simbólica que se instituye a través del régimen de significación que contiene a partir del reflejo, reflexión y construcción de lo real y lo común. Más allá de los individualismos o de la sumatoria de los mismos que la producen, configura sinergias, porque propone una apertura intersubjetiva que se reconoce como excepcional para la colectividad en la que se inscribe al problematizar sutilmente esas formas de entender lo común.

Lo común en este caso se estructura justamente en el lenguaje, en la posibilidad de construir sentido como una forma de comprender, asir y estar en el mundo. Crear sentido tiene que ver con establecer o propiciar formas de ver, de comprender la realidad, a modo de intercambio simbólico y construcción de identidad, que se produce en la intersubjetividad. A través de las modalidades de la experiencia estética se están configurando comunidades de sentido al generar apertura en las significaciones y en la producción de nuevos sentidos.

Pero es una comunidad que está problematizando los límites instituidos de la significación, con respecto a lo que quiere decir ser víctimas, ser jóvenes, ser habitantes de un sector específico de Medellín, etc. Al hacer evidentes esos límites, se genera una dislocación de la significación, que permite visibilizar las contradicciones, las estructuras de poder, los antagonismos, las disputas entre identidades, entre percepciones sobre lo que era "normal", lo que Laclau señala como "equivalencias de lo social” (2004), que producen consensos e imaginarios 
aceptados colectivamente y a partir de los cuales se establecen las subjetividades, las identidades, es decir, lo social.

Cuando la experiencia estética permite hacer visibles esos límites de lo social, los devela y problematiza como algo dado, se configura como experiencia limítrofe que disloca los límites de la significación e introduce la posibilidad del acontecimiento y resignificación del mismo sistema.

Lo sumamente importante de la experiencia estética es que genera una apertura de sentido que permite que una cosa se convierta en otra distinta, es decir, posibilita transfigurar la realidad, cambiar radicalmente el aspecto de algo, alguien o un imaginario, sin limitarse a lo que está instituido; esto es dislocar la realidad, y se parece de alguna forma a la construcción de conocimiento, un conocimiento que pasa por lo sensible, por un régimen de significación diferente al instituido por el logos. Dislocar la realidad se puede entender como introducir aperturas de mundo que permitan ver y pensar otras cosas que no son percibidas cotidianamente, tiene que ver con construir espacios y relaciones diferentes que posibiliten reconfigurar simbólica y materialmente el mundo de lo común.

Este arte no es instauración del mundo común a través de la singularidad absoluta de la forma, sino la redisposición de los objetos y de las imágenes que forman el mundo común ya dado, o la creación de situaciones dirigidas a modificar nuestra mirada y nuestras actitudes con respecto a ese entorno colectivo. Estas micro-situaciones, apenas distinguibles de las de la vida ordinaria y presentadas en un modo onírico y lúdico más que crítico y denunciador, tienden a crear o recrear lazos entre los individuos, a suscitar modos de confrontación y de participación nuevos. (Rancière, 2005, p. 16)

La apertura que propicia la experiencia estética es dibujar o hacer aparecer un espacio común diferente, un espacio donde se generan nuevas relaciones de sentido entre los diferentes ámbitos de lo humano, donde la experiencia vivida se articula complejamente y genera relaciones entre la vida cotidiana y lo político, entre la realidad y la oportunidad 
de soñar, de construir otras posibilidades de acciones en vínculos diferentes a los instituidos; esto produce otros sentidos, otras prácticas, otras expectativas sobre lo común.

Las formas de la experiencia estética son las formas de una comunidad de sentido por venir, como afirma Deleuze, que se configura dinámicamente por la acción, por la ampliación de significación que se produce entre los receptores y productores de la experiencia estética, y que posibilita transformación, un movimiento, un acontecimiento.

Para Deleuze, "el acontecimiento es el propio sentido y pertenece esencialmente al lenguaje, es aquello del mundo que se deja envolver en el lenguaje y le permite funcionar" (Zourabichvili, 2007, p. 13) y que hace presencia en lo que sucede, no en el hecho mismo, es un cambio en el ámbito del sentido. El acontecer tiene que ver con la exploración de la conformación de las palabras, con ese momento de la apropiación, el momento cuando eso o aquello está referido al ámbito de lo propio, como revelación de lo propio del ser y su devenir. "El acontecimiento es ingobernable y, por otro lado, siempre sucede. Ello significa que el hombre libre se sostiene dentro de lo ingobernable, dentro de lo incierto, no reduciendo o controlando el acontecimiento, sino dejándolo efectuarse completamente en él, y afirmándose con él, como creador" (Gómez, 2011, p. 141)

En esta perspectiva, el acontecimiento afecta la transformación del sujeto, vía la construcción de sentido, pues es este el que se afecta o modifica en el hecho, y es aquí donde cobra importancia el carácter singular que propone la experiencia estética como una situación prefigurada por la singularidad del hecho mismo, por su carácter irrepetible e inédito.

Así, el acontecimiento se presenta como un hecho capaz de perturbar, movilizar y configurar otros ámbitos de la experiencia sensible que no están reglamentados, pues el sentido que se produce a la par en el acontecimiento puede dislocar los significados instituidos colectivamente porque en esencia es una apertura, dado que no hay anticipación. "Ese acontecer implícito en la experiencia estética revela lo inacabado, la fuerza de la finitud y al mismo tiempo la apertura: es privilegiada pues hace evidente esa apertura inconmensurable que no se reduce a un marco de significación estricto" (Mier Garza, 2014, s. p.). 
El lenguaje a través de múltiples formas de expresión, en este caso a través de una representación teatral, de un audiovisual o a través del juego, se presenta como práctica que deviene acontecer.

Para entender el acontecimiento que propone la experiencia estética hay que entenderlo primero como experiencia afectiva, como elemento central de lo estético, "que suscita un modo particular de racionalidad y una experiencia vital de lo exorbitante que se escapa a la aprehensión conceptual, la cual busca todo lo contrario, una concepción de finitud" (Mier Garza, 2014, s. p.). La experiencia estética reclama una condición de inteligibilidad inacabada y abierta, es decir, de apertura a una significación que no se extingue, que no tiene patrones ni confines.

La expresión estética como potencia es ante todo de apropiación individual, particular o singular, que se inscribe en lo irreductiblemente propio de cada agente; por lo tanto, no se puede anticipar, prever o calcular. Las expresiones que se analizarán son una construcción grupal que hace parte de las condiciones particulares de cada grupo y de cada agente comprometido, de ahí su carácter inédito. Además, también vale la pena señalar que la experiencia propuesta por estos grupos solo puede tener juego en el encuentro con el otro, con las audiencias, es decir, reclaman una condición o existencia de otro, para que tenga sentido en sus variantes o aperturas de significación y afectación.

De esta manera, la experiencia estética es ante todo un espacio que posibilita un agenciamiento colectivo de enunciación que se configura contingentemente, y que se produce como una alteración de los espacio-tiempo de lo cotidiano, lo que genera otros vínculos, la alteración de sentidos ya instituidos y la constitución de nuevas significaciones o concepciones de lo social y prácticas que producen otras formas de habitar lo común en la esfera que habita cada agente. Es la creación de nuevas formas de saber y operar sobre sí mismo, para operar sobre el mundo, en el vínculo con los otros, en un espacio-tiempo específico que le confiere sentido a la práctica.

Es precisamente a través de metáforas específicas narradas o activadas a través del teatro, el juego o el audiovisual, como los creadores -en este caso, los y las jóvenes que las producen, operando sobre sí mismos- posibilitan actuar sobre el mundo, un mundo compartido con otros. Es decir, a través suyo, de su corporalidad y capacidad de 
invención, se crean metáforas que permiten la ampliación de otros límites, tanto subjetivos como identitarios, que son puestos en juego colectivamente al momento de su realización, presentación o proyección, y es justo en ese momento cuando se presentan las condiciones del acontecimiento entre el público y los realizadores, pues se despliega como una intervención de lo cotidiano, que afecta los modos de pensar, percibir y actuar sobre el presente, en un contexto histórico y territorial específico.

Para Schiller sólo a través de la metáfora es posible acercarse a la calidad expresiva de la experiencia estética, es gracias a esta representación metafórica que se pueden crear condiciones de inteligibilidad. Esta es una experiencia receptiva, pero tiene que poner en juego la imaginación para esta posibilidad, una imaginación creadora, pues es la imaginación la que permite la experiencia. La imaginación creadora es una incorporación sintética de sensibilidad y capacidad de creación de ideas, por tanto es expresión, propiamente simbólica que permite transitar de esta operación de síntesis entre proceso de ideación, operado por la imaginación a una operación simbólica. (Mier Garza, 2014, s. p.)

Al suponer que la experiencia estética se produce gracias al uso de metáforas, es posible comprender la apuesta de estos jóvenes por hacer aprehensible su pensamiento-acción a través de la metáfora del teatro, el juego y el audiovisual como propuestas creativas de acción que permiten afectar o alterar los espacios y tiempos que habitan, en un contexto específico como Tumaco y Medellín. A continuación, se presenta un análisis de su apuesta estética desde la comprensión de sus contenidos, de cómo los producen, del para qué implícito, de su proceso de creación, los aprendizajes construidos y cuáles son las estrategias de argumentación que mantienen en cada obra, audiovisual o espacio.

\section{Teatro por la paz: el teatro del oprimido}

Las obras de teatro que produce este grupo dan cuenta de la realidad que viven las y los habitantes de Tumaco, a partir de un proceso de recuperación de memoria ancestral, a través de danzas, arrullos, alabaos 
o prácticas funerarias como el Chigualo, asociados a elementos que configuran la cultura afrocolombiana propia de esta región. Es una mezcla permanente entre cotidianidad, fiestas tradicionales y narración de acontecimientos de violencia desde la perspectiva de las víctimas, que tienen como intención hacer un ejercicio de memoria histórica que busca resignificar la condición de víctima y contribuir de alguna forma a esclarecer la verdad ante los hechos violentos que han marcado la historia de esta comunidad.

Los contenidos de las obras se nutren de casos de la vida real, de historias narradas por las víctimas y la realidad que viven los participantes del grupo, fruto del proceso de reflexión entre ellos y la profundización de los casos que llegan a la Pastoral de Tumaco.

Primero se hacen los encuentros, lo que pensamos, qué temática queremos abordar en esta semana por la paz, decíamos que la simbología de lo que son las comparsas, la murga, como rescatando todo eso tradicional que ya hemos perdido, pero que va en la misma línea de lo que hemos venido trabajando, la denuncia, la incidencia y todo eso. (Nohora, 20 de mayo de 2014, entrevistada por Molina, I., Tumaco)

La obra Mi otro yo fue sacada del informe de la Diócesis de Tumaco de unos casos que están en el banco de datos, y la diferencia es que la parte de la obra de las Tumatai de mi otro yo, mencionamos nombres reales de víctimas, pepita Pérez fue asesinada, acribillada. (Mary Cruz, 23 de mayo de 2014, entrevistada por Molina, I., Tumaco)

De esta manera, el teatro recrea un poco la realidad social y cultural de esta población del pacífico colombiano. La violencia en esta ciudad no es aislada y las obras de teatro beben de esa situación. A continuación, se muestra un poco de esa verdad narrada por una de las integrantes y su interrelación con los contenidos de los montajes:

Más o menos el 2007 volvió a coger fuerza, asesinatos selectivos, masacres, mataban 3, 4 ó 5 personas en el día, entonces todos esos 
movimientos han tenido repercusiones en las comunidades y en la sociedad, ese silencio, ese querer auto-protegerse y por eso se decide callar, también esa normalización de la violencia, pues todos los días había muertos, a veces en el mismo día varios, en las zonas de los municipios aledaños a Tumaco que hacen parte de la Costa Pacífica, donde está todo el tema minero también ha habido mucha violencia, también por las disputas por el territorio, también el asesinato por personas por el tráfico del oro.

De ahí surgió la escena de la obra "El olvido está lleno de memoria” “¡CAVÁ!” esa historia es el testimonio de una de las víctimas que también está en el informe que escribe la Diócesis, que se llama: Que nadie diga que aquí no pasa nada. Es un informe sobre la situación de violencia de los municipios de la Costa Pacífica Nariñense, que son jurisdicción de la Diócesis.

A él lo obligaron a cavar la fosa donde masacraron más o menos entre 15 y 20 personas que fueron los mineros que trabajaban en ese socavón para sacar oro, y a esta gente no les querían pagar su dinero y lo que hicieron fue que al dueño de la retroexcavadora pedirle que hiciera el hueco y cuando ya estuvo hecho el hueco entonces ya se dio cuenta que era para matar a la gente y no pagarles, y a él también le dispararon y él fue el último porque ¿quién les iba a tapar el hueco? Entonces cuando ya terminó todo le dispararon, el señor se hizo el muerto, y se dejó llevar por el río, y luego ya en una parte donde ya él pudo salir, entonces se fue entre la maleza del monte, cortando trocha, rastrojeando, como se dice en esta zona, hasta que llegó a un sitio donde lo atendieron y contó lo que pasó, y el señor fue sacado de la zona, pero él quedó con unas secuelas psicológicas muy fuertes, y él era el que contaba que quería destruirse las manos porque de alguna manera se sentía culpable y decía que sus manos habían hecho parte, también se sentía homicida, y que sus manos se habían prestado para asesinar a esas personas, el horror, la cara de esas personas, gente que era de la misma zona, gente que había venido de afuera, de 
otros territorios, de otros departamentos a trabajar, dejando sus familias, por venir a buscar un trabajo. (Karen, 15 de mayo de 2014, entrevistada por Molina, I., Tumaco)

Así, los relatos descarnados de las víctimas se recrean en las tablas, la impunidad, la tristeza, la desazón y el desamparo de muchas personas que no entienden por qué mueren sus familiares o vecinos. Sin embargo, esta dosis de dolor solo puede ser soportable en la medida en que se alterna o se presenta con música, danza y simbolismo. En las obras se hace evidente una postura que rechaza estos hechos, pero que reivindica además la posibilidad de un mañana diferente, de una versión sentida desde el dolor de lo propio, de la ritualidad de lo ancestral que permite tramitar social e individualmente estos hechos para rechazarlos, reivindicar la condición de víctima y poder continuar con la configuración de un "nosotros vivo" en comunidad. Es decir, los relatos y la crudeza del dolor no se quedan solo en mostrarlos; por el contrario, se busca resignificarlos para poder rechazarlos o juzgarlos socialmente (cosa que se pierde cuando el silencio y el miedo se convierten en el común denominador) para exigir su no repetición.

Una de las actuaciones más difíciles para el grupo Teatro por la paz fue su presentación ante unos paramilitares que se sometieron a la Ley de Justicia y Paz, y quienes debían "explicarle” a las víctimas por qué habían cometido los asesinatos por los que estaban imputados. Esta presentación se hizo en la Casa de la cultura de Tumaco, en 2014, ante los pobladores y los asesinos de muchas víctimas.

Ahí hicimos "El olvido está lleno de memoria" pero, bueno, tenemos muchas obras pero dependiendo de la ocasión hacemos fusiones, o sea un pedacito de una, de otra, y entonces en el último pedazo metimos algo de mi otro yo, donde se contaba la historia de la hermana Yolanda y otro casito, y ellos eran los asesinos de Yolanda, y yo soy Yolanda en la obra, la muerta, mi hermana la viva, y entonces, estaban ahí y yo decía yo soy tal, me asesinaron el día tal...y ellos se quedaban viéndolo a uno normal, ahí estaba el que la mandó a matar y el que la mató. (Johana, 19 de mayo de 2014, entrevistada por Molina, I., Tumaco) 
Esta experiencia fue difícil para toda la comunidad y también para los integrantes del grupo de teatro, porque fue una forma específica de manifestar el reclamo, repudio e indignación hacia los líderes de los paramilitares que esta vez tenían rostro. Para el grupo, la presentación permitió abrir la sesión, transmitir un poco de la indignación y repudio frente a los asesinatos selectivos, desde una voz diferente, desde una puesta en escena que apela a los sentidos, a despertar sensaciones y producir el recuerdo a partir de las historias y la memoria de las personas que perdieron la vida en el pasado reciente de este municipio.

De esta manera, la estructura de las obras se alimentan de casos específicos, de hechos y víctimas reales que son reivindicados, pues como dicen los actores: de los asesinos se habla, ¿y del muerto?, no, y mucho menos de lo que sienten y piensan los familiares de esas víctimas, de los traumas con los que se alimentan, del imaginario que impera sobre los hechos de violencia o sobre las implicaciones de estos hechos para entender la vida y la muerte en Tumaco.

Mi otro yo relata la vida de una víctima, cuando está viva, ella cuenta que tenía unos hijos bien hermosos, que los quería mucho, nosotras con Alicia, interpretábamos a una joven de 27 años. Alicia hace el yo y yo, mi otro yo. El otro yo, es la persona que piensa ya como fallecida, de que si ella no hubiera ido a tal lugar no la habrían matado, en cambio el yo cuenta todo lo bonito que era cuando estaba viva, es una obra muy bonita. (Nohora, 20 de mayo de 2014, entrevistada por Molina, I., Tumaco)

En esta obra, los vivos y los muertos bailan y recuerdan juntos el pasado, los nombres, ocupaciones, sueños y los interrogantes de aquellos que murieron sin explicación, evocando a líderes de la comunidad y a personas del común que perdieron la vida violentamente. Cuando empieza la obra, el recuerdo vivo de los muertos y estos exclaman conjuntamente: "Cuando sepas que estoy muerto, no pronuncies mi nombre. Di sílabas extrañas: tristeza, soledad, lágrimas, dolor, injusticia, guerra, tormenta, impunidad". Pareciera que no hay distingo entre los muertos, los vivos o los recuerdos de aquellos que no están; juntos conviven en las iglesias, en la playa, en las casas o en las calles de 
la ciudad, y se vinculan mutuamente gritando: "Cuando sepas que estoy muerto y haya paz en mi ciudad, di sílabas de reconciliación: flor, abeja, pan, amor, solidaridad, dignidad, justicia" (Teatro por la paz, 2010. Fragmento de la obra Mi otro yo).

Como se puede apreciar, el teatro, entre otras cosas, se vale del uso de metáforas para transmitir ideas y representaciones sobre la realidad. En este caso, producen relaciones de sentido a partir de la exposición de relatos, establecen comparaciones entre elementos para descubrir otras características o atributos sorprendentes frente a algo o alguien. Por ejemplo, en la obra La gran comarca de la Tonga se presentan diferentes situaciones en el transcurso de la obra, que parecen desarticuladas, pero que en conjunto están representando la realidad de la violencia, no solo desde el punto de vista de la espera de los desaparecidos, de las razones estructurales que contribuyen a un ambiente de zozobra y violencia, sino también a los mitos fundadores de la cultura afrocolombiana, aquellos que tienen que ver con las deidades que acompañan a los hombres en este paso por la tierra y que orientan su acción, a los cuales se veneran en los carnavales, en las fiestas o con los alabaos y arrullos.

En esta obra la alegría y euforia de las celebraciones tradicionales de origen africano se alimentan de los duelos, de la tristeza, del dolor y la ausencia de aquellos cuerpos inertes a quienes los vivos siguen cargando en su espalda. En la obra, los muertos se representan con prendas de ropa como vestidos, camisas, chaquetas que en ganchos flotan en el escenario y que permiten entender que solo eso queda de los que ya no están; por eso un desaparecido que se presume muerto exclama: “¿Lo ves? El silencio, ¿lo ves? [...] Aún hay algo de mí: una foto, un traje, un velorio que espera y una razón para esperarme [...]” (Teatro por la paz, 2012. Fragmento de la obra La gran comarca de la Tonga).

El uso de estas metáforas como una forma eficaz de transmitir significantes a través de la puesta en escena produce una articulación de vínculos y sentidos que aparentemente no tienen nada que ver con este tipo de lenguajes, de lugares o de actores; es decir, con el teatro, con el tiempo de ocio, con los jóvenes, con lo "sensible". Este es uno de los elementos por destacar de la experiencia estética a través del teatro, que permite vincular diferentes regímenes de expresión y de 
representación que abre posibilidades de enunciación más fructíferas, como señala Rancière (2011). Solo así es posible entender que a través de estos montajes los jóvenes y las mujeres que participan en este tipo de procesos pueden hacer de su expresión corporal una manifestación explícita de lo político, de poder hacer visible otros agentes, otras subjetividades o representaciones frente a la muerte, a la violencia, e incorporar al ámbito de lo público la inconformidad, la oposición o el antagonismo como una oportunidad de creación, en este caso de espacios de participación y socialización diferentes, de creación de lenguajes verbales y no verbales que reivindican al cuerpo como dispositivo de enunciación, y a los jóvenes como agentes visibles y significativos en los diferentes ámbitos que configuran lo social.

Así, los montajes teatrales ponen en evidencia otras formas de lenguaje y argumentación que responden a unos agenciamientos discursivos propios de la experiencia estética, los cuales se inscriben al ámbito de lo cotidiano, porque apelan a una sensibilidad corporal, festiva, que no es ajena a la cultura afro y que resulta cercana para la comunidad, a partir de la cual plantean una ruptura con esa partición que impone el ámbito de la política, donde se formaliza el lenguaje y se establecen protocolos y formas particulares de decir y hacer. Estos montajes lo que están posibilitando es la inclusión en el ámbito de lo público de otras lógicas de enunciación; por ejemplo, desde la condición juvenil, donde se plantean o sugieren otras posibilidades de denuncia, de acción, de oportunidad de nombrar la realidad, de indignarse y reflexionar sobre los hechos violentos que han marcado a los habitantes de este sector del país.

Pero este agenciamiento no se limita únicamente al nombrar la realidad, a ampliar los matices que la constituyen y a visibilizarlos, o a vincular ámbitos a partir de los cuales tiene sentido la acción social, sino porque provocan o inducen a su posible transformación, es decir, porque convocan a la acción. El pasado al que se remiten las obras, bien sea lejano o cercano, solo tiene sentido cuando se convoca para pensar el presente y producir otras pistas para soñar el futuro.

Uno de los mecanismos de enunciación que este grupo emplea permanentemente en los montajes es la búsqueda de sentido en las prácticas ancestrales culturales propias de este sector del país, no solo como fuente de inspiración —en lo que tiene que ver con la danza, los cantos 
y la música一, sino también con las prácticas religiosas que permitían articular la idea de un "nosotros" y que configuraba en épocas anteriores formas complejas de entender la vida y la muerte, lo privado y lo particular, la tristeza y la alegría. En una de sus obras recientes, titulada El olvido está lleno de memoria, el grupo acude a traer al presente una fiesta ancestral de velación, mejor conocida como el Chigualo: "es una celebración que hacen adultos y niños durante el velorio de un niño muerto, para que el ánima del niño muerto, libre de pecado emprenda el viaje hacia el cielo donde se convertirá en un angelito" (Red Nacional de Mujeres Afrocolombianas-Kambirí, 2013, p. 38). Durante el proceso que se desarrolla en la noche y hasta el amanecer, los asistentes juegan, conversan y cantan arrullos, en honor al alma del difunto.

A las 5 am, se despide el espíritu del niño muerto, los padrinos y acompañantes colocan al angelito sobre una sábana blanca y lo pasean por todo el cuarto, marimbeándolo y cantándole en coro: buen viaje [...] Al niño muerto no se le puede llorar demasiado porque las lágrimas derramadas se convierten en una inmensa laguna que le impide el paso hacia la morada eterna. (Red Nacional de Mujeres Afrocolombianas-Kambirí, 2013, p. 39 y 40)

En El olvido está lleno de memoria, el Chigualo se convierte en la oportunidad de despedir a aquellos que, como el niño difunto, son inocentes, pero que han muerto de forma violenta, por eso se les acompaña a su partida y despedida, con un arrullo que canta:

Buen viaje, buen viaje

Al que se embarca y se va,

Buen viaje,

Buen viaje, buen viaje,

Tu familia te ha de dar,

Buen viaje.

Sin embargo, no siempre las víctimas mueren; algunos sobreviven y en el ejercicio del recuerdo, que como pesadilla acude a sus noches, el hecho se recrea y va consumiendo la tranquilidad de aquellos que en 
carne propia experimentaron la violencia. Este es el tema central de la obra, las noches de aquellas personas que son victimizadas nuevamente a través de la inclemencia del recuerdo. En medio de la presentación, una especie de narrador recita un poema del libro de Benedetti, que lleva el mismo nombre:

El olvido está tan lleno de memoria

que a veces no caben las remembranzas,

$\mathrm{y}$ hay que tirar rencores por la borda

en el fondo el olvido es un gran simulacro

nadie sabe ni puede /aunque quiera/ olvidar

un gran simulacro lleno de fantasmas...

(Benedetti, 1995. Fragmento del poema Ese gran simulacro)

En medio de estas posibilidades de expresión que se transmiten en la puesta en escena, este tipo de montajes apela a entender que en el ejercicio del recordar, de evocar el pasado reciente o ancestral, los asistentes son incitados a traer al presente el pasado, aunque sea un ejercicio doloroso, a no olvidar, a evocar momentos clave que marcan a un cuerpo, a una familia y a una comunidad entera. Son montajes que dejan huellas imborrables, no solo en el recuerdo singular, sino en la memoria colectiva, que va alimentando imaginarios, que legitima actores y prácticas, pero que desconoce a otros y condena al olvido a la verdad, a la reparación, al derecho al nunca más.

Lo que este tipo de obras busca es convertirse en un dispositivo mnemotécnico que cumple una función social de convocar al recuerdo, de reconocer los hechos, de sacar del olvido a las víctimas, de convocar a la reflexión sobre los hechos violentos a través de un régimen de significación sensible que problematiza ese imaginario de que no hay nada que hacer, que los muertos muertos están, que no tienen derecho a ser llorados porque se les asocia como corresponsables de su muerte; es oponerse a la imposición del olvido como práctica socialmente validada.

En esta puesta en escena no solo se busca posicionar el ejercicio de memoria, sino también de activar el recuerdo y configurar otra 
versión del olvido como elemento clave para pensar y configurar el territorio, para repensar el nosotros, para problematizar la identidad y las relaciones de poder que determinan cómo recordar, qué tipo de prácticas y qué roles desempeña la comunidad, los damnificados, los jóvenes, las mujeres. En estos montajes no solo se presenta una versión de los hechos, sino que además se posicionan subjetividades, se desmitifican verdades, se exponen otros valores, otras reflexiones en torno a la vida, a la muerte, a la identidad tumaqueña, al pasado, al presente y sobre el futuro.

El ejercicio de memoria en estas obras tiene implícito un fin político, en el sentido de que se configura como un ámbito de reflexión y de tensiones que visibiliza otras lecturas, otros agentes, y que se opone a un único relato sobre las víctimas, sobre los hechos violentos que marcaron la historia de Tumaco. Es un ejercicio que problematiza las representaciones del pasado y que posiciona a las víctimas como agentes capaces de proponer un discurso, no solo como sometidos — revictimizándolos—, sino además exaltando la posibilidad de construir a partir de las otras versiones del pasado, a no olvidar lo que el dolor y la muerte producen en los agentes y en la sociedad en general, con una intencionalidad explícita de no repetición. También es un ejercicio que ayuda a configurar al ejercicio de memoria como un mecanismo que permite reflexionar sobre el territorio, las relaciones que lo configuran, la comunidad, la potencia de los agentes y las posibilidades infinitas de construir un presente diferente. En fin, es la posibilidad de confiar en los jóvenes del teatro, el poder participar en los procesos de construcción de la memoria colectiva de Tumaco.

Como estrategia de enunciación, el grupo ha logrado establecer un mecanismo que les permite presentar su trabajo a diferentes públicos, siempre innovando, articulando temas, historias y formas de contarlas: "nosotros hacemos una obra madre y luego la vamos adaptando dependiendo de las circunstancias, le vamos agregando más cosas" (Mary Cruz, 23 de mayo de 2014, entrevistada por Molina, I., Tumaco). De esta manera, cada obra se adapta a las circunstancias, y permite así que los discursos y los relatos puedan ser combinados sin dificultad, dependiendo de los públicos a los que se presentan. No obstante, la intención permanece: hacer un llamado a la reflexión, resaltar 
las narraciones de las víctimas con el fin de oponerse a la doble victimización que sufren; se procura visibilizar el sentir de estas personas buscando también que se fortalezcan a partir de las reflexiones que se proponen en cada presentación.

Por ejemplo en la iglesia hay mucha gente que llora, y que dicen, a mí me pasó tal cual, ¿cómo saben? Una señora me dijo, mire a mí me pasó tal cual como usted lo dijo, eso fue en Mi otro yo, la hicimos para el aniversario de la hermana Yolanda en el 2010, bueno la obra te muestra la historia de una persona que la interpretan dos personas, una cuando está viva y la otra cuando está muerta, entonces cuenta cómo era, lo que hacía, por qué la mataron, qué pasó cuando la mataron, cómo la mataron, a quiénes dejó y sus familiares, entonces los familiares cuando mi hijo se murió fue así, tal cual, o sea, cuando tú te mueres está tu otro yo que cuenta cómo eras, y en este caso es la familia, la mamá que cuenta mi hijo era así, asa, y ella me decía, con migo pasó tal cual, así era yo y cuando mi hijo se murió así me volví, y la gente también dice: debemos salir adelante, y luchar por nuestros derechos, saber que no los estamos mendigando, que nos corresponden, no tendríamos por qué pedirlos, porque son nuestros, pero pues así toca. Pero yo creo que sí hemos logrado lo que hemos querido, que era dejar ese mensaje en todas las personas que han visto las obras. (Johana, 19 de mayo de 2014, entrevistada por Molina, I., Tumaco)

Uno de los recursos simbólicos de enunciación que emplean los actores en los diferentes montajes es interpelar con los ojos al público, con el fin de que el contenido o la historia impacten en el auditorio y generen reflexión, que el público no quede inmune ante la fuerza de la violencia representada en cada escena. Asimismo, se busca que en todas las obras se presenten casos reales de víctimas, que se hacen presentes en fotografías, con su nombre y año cuando desaparecieron o murieron. Esto con la idea de que la realidad siempre acompañe al ejercicio de mímesis que se presenta en las tablas.

Otro recurso que es importante dentro del grupo tiene que ver con el cuidado de sí, por decirlo de alguna forma, pues la carga psicológica 
que implica para los actores representar este tipo de historias es muy fuerte, así que se implementan permanentemente procesos o ejercicios de autoconocimiento, de cuidado de cada uno. Es un principio impreso en la esencia del grupo, pues le permite a los participantes, antes que otra cosa, soltarse, generar vínculos diferentes al miedo, construir autoconfianza y confianza entre los compañeros.

Después que terminamos la semana por la paz descansamos el siguiente sábado y al otro evaluamos cómo se sintieron, cómo se sienten, uno puede hablar de todo, luego de eso hacemos ejercicios de autocuidado, de concentración, de mimarnos nosotros mismos, ejercicios de respiración, cada sábado hacemos algo diferente de tal forma que a medida que va pasando la semana vamos soltando, vamos descargando todas esas emociones y cosas que durante la semana recopilamos, porque es muy fuerte cargarse de tanta cosa, y como son presentaciones así muy continuas el desgaste físico y el desgaste emocional es bien fuerte. (Nohora, 20 de mayo de 2014, entrevistada por Molina, I., Tumaco)

Con esto, se problematiza la condición de lo que significa ser víctima; no es victimizar nuevamente a los que han sufrido la indolencia de la violencia, sino dar la oportunidad de compartir con otros el dolor, los miedos y los traumas que produce el tener un muerto en la familia, de contar su ocupación, su nombre y desligarlo de la idea de que algo debía, o que pertenecía a cierto grupo. Es la oportunidad de reivindicar a la víctima públicamente y exigir nuevamente “justicia”. La importancia de visibilizar casos de la vida real está articulado a esta intención, por eso en las obras se apela a mostrar las diferentes caras de la violencia, de género, desapariciones, violaciones, asesinatos selectivos por la reivindicación de derechos, las masacres vinculadas a la explotación minera, el desplazamiento, la violencia estructural, el acoso a los jóvenes para que se vinculen a los grupos armados y las consecuencias de estos actos en el tejido social, como el miedo, el silencio, el dolor, la desconfianza y la desarticulación social.

La posibilidad que representa el hacer los montajes y presentarlos ante la comunidad en espacios culturales, religiosos o coyunturales 
contribuye a romper con ese mandato de silencio y de miedo ante la realidad imperante; es producir escenarios de diálogo, de reflexión y de afectación que visibiliza actores y prácticas que se asumen obvias, pero que aún no se han procesado colectivamente, es decir, que aún están cargadas de silencios, de estigmas y se han invisibilizado. Actores y prácticas que se someten al olvido para poder continuar como sociedad, pero que individual y colectivamente siguen produciendo rupturas y consecuencias improductivas socialmente hablando. Es justo al hacerlas visibles o enunciables cuando se pueden reelaborar y dotar de sentido productivamente para entender el presente y construir un futuro de no repetición.

De igual manera, el teatro se convierte en un escudo que les permite a los agentes de una comunidad —en este caso los jóvenes- expresarse sin miedo a tener represalias por manifestar su desacuerdo y por exigir justicia y reparación ante los hechos.

Ha ayudado a visibilizar y a demostrar que hay muchas formas de decir lo que pasa sin ponernos en riesgo, por ejemplo, todos sabemos que si pasa algo, no lo puedo decir porque me pasa algo a mí también, pero hay muchas formas de decir que no estamos de acuerdo con cosas: yo no soy capaz de salir y decir hoy pasó tal cosa, y yo vi, y eso es así y esto, pero a través del teatro yo soy capaz, porque digamos que es mi escudo, es mi blindaje, yo creo eso y ha servido para que la gente se exprese, para conocer lo que pasa. (Johana, 19 de mayo de 2014, entrevistada por Molina, I., Tumaco)

Este tipo de estrategias permite que los jóvenes se vinculen al ámbito público desde una lógica de argumentación diferente, mediada por la experiencia estética, que produce una suerte de ruptura primero con la lógica discursiva predominante; es decir, que apela al lenguaje corporal, a la expresividad a un régimen de enunciación que prioriza la afectación a lo sensible, que dista de la lógica de argumentación especializada y mediada por la ley que establece la democracia para participar en lo público. Segundo, amplia el ámbito de intervención sobre lo visible y lo enunciable; esto quiere decir que configura al teatro como espacio de lo político, que permite la institución de otros significados, 
de otros valores, de otras perspectivas frente a la realidad, frente al pasado, frente a los protagonistas. No se supedita únicamente a la intervención del Estado para establecer marcos de interpretación de la realidad; es entre los tumaqueños, a partir de estos espacios, que se generan posibilidades de construcción de sentidos sobre la historia reciente de la ciudad, sobre los puntos en los cuales hay que trabajar colectivamente para continuar ordenando lo común.

Teatro por la paz es un teatro social, que aborda temas sociales que se viven en la comunidad, que se viven en el territorio, que no son inventos nuestros, sino que son vivencias propias, que la gente se identifica con ellas, tanto el público que asiste a las presentaciones como los integrantes de teatro por la paz, es un teatro que nosotros lo construimos por medio de la investigación, digamos son construcciones nuestras. Es un teatro de creación colectiva, basándonos en algunas técnicas del teatro del oprimido, que es un teatro para trabajar temas sociales, y para visibilizar o denunciar atropellos que sufre la comunidad o situaciones de opresión, es un teatro que nos permite expresar lo que sentimos, por eso lo sentimos tan propio y además de ello es un teatro que ayuda a las víctimas, se sienten identificadas, hacen un proceso como de desahogo también, porque cada vez que nos presentamos hay gente que se nos acerca y nos dice "yo me identifiqué con lo que ustedes dicen" $[\ldots]$ nosotros siempre en esos espacios tratamos que después de las presentaciones hacer como un conversatorio, a ver cómo se siente la gente, qué piensa, qué es lo que ve. Y eso lo hacemos también como una forma terapéutica, porque también a veces la gente se siente avergonzada de decir lo que piensa, porque se sienten culpables, es tan fuerte la situación de conflicto que la gente siente como que nosotros [ellos mismos] tienen la culpa de lo que está pasando, como que las víctimas tienen la culpa, porque hemos llegado al punto de señalarnos, mataron a un joven ¿en qué estaría?, ¿qué estaría haciendo?, ¿a qué grupo pertenecería?, digamos, estamos estigmatizando también a la víctimas, entonces este teatro nos permite a nosotros también hacer ese acompañamiento a las víctimas, y decir que no es normal que esté pasando 
esto, que nadie es culpable, que nosotros no somos los causantes de esta guerra, nosotros somos víctimas y como víctimas tenemos derecho a hablar, ya que se nos niegan tantos derechos, ese derecho de hablar no nos lo pueden quitar, entonces yo pienso que esa es una característica fuerte de este teatro, que permite acompañar a las víctimas, hablar por las víctimas, que permite bueno usted tiene derecho a hablar de lo que siente y lo que le pasa, hágalo, ocupe este espacio que es un espacio para ustedes, que es un espacio de acompañamiento a ustedes. (Mary Cruz, 23 de mayo de 2014, entrevistada por Molina, I., Tumaco)

El teatro es una oportunidad de darle rostro y voz al dolor, de nombrar la violencia que la gente de Tumaco ha vivido, es una forma de enunciación, de denuncia y de posibilidad de transformación en oportunidades, pues permite resignificar la realidad y generar espacios de reflexión para transformarla en la cotidianidad.

El teatro contribuye a esto, porque es una forma didáctica, es una metodología diferente que nos ayuda a tener voz, a darle un rostro al dolor, a la inconformidad, nos permite darle voz al desespero y a la angustia de la gente, es también cómo la madre tierra, la naturaleza sufre y darle voz también a esa tierra que nos ha visto crecer a todos nosotros y que pisoteamos. (Karen, 15 de mayo de 2014, entrevistada por Molina, I., Tumaco)

Para que esto suceda, primero la reflexión tiene que pasar por los participantes del grupo, de los jóvenes, quienes para producir esas obras se interesan por conocer qué sucede, por qué la violencia, por qué se mantienen esas dinámicas; es un ejercicio de reflexión permanente que se materializa creativamente en el teatro como una forma de denuncia y de aporte a la sociedad.

Uno de los logros significativos es que los integrantes del grupo teatro por la paz son muchachos que reflexionan su realidad, que tienen claro qué es lo que quieren, que saben que lo que se está haciendo es un trabajo serio, que ellos hacen parte de ese trabajo y que aportan a lo que está pasando, que ya no se sienten como 
a mí no me toca hacer esto, yo no tengo que ver con esto, que la solución ya no la busque otra persona sino que ya se siente parte de esa solución, de lo que está pasando en Tumaco. Para nosotros eso es importante porque son espacios que se dan para la expresión. Y que siempre que nos encontramos tenemos espacios para reflexionar, y que ellos sean capaces de reflexionar, que seamos capaces de reflexionar sobre la situación es un logro que se ha hecho por la paz, eso no pasaba antes, porque la situación y desconfianza en Tumaco es fuerte, porque nadie confía en nadie, hablar del tema de violencia, de la situación de conflicto que pasa incluso en las propias familias no es un tema que uno pueda hablar abiertamente, sin embargo, en teatro por la paz ya se tiene esa costumbre, entonces conversamos sobre la situación, cómo se sienten, cómo nos sentimos, cómo estamos en nuestras familias, en nuestros barrios, qué pasa en nuestros barrios, entonces ellos ya tienen la confianza de contar ve en mi barrio está pasando esto y esto, o escuché que en mi barrio pasa esto y esto, eso es un paso que se ha dado por medio del teatro, porque se ha dado el espacio de confianza, además que tenemos una regla, que lo que sucede en el teatro se queda ahí, es una estrategia, que todo lo que comentemos, que hagamos en las salidas, si pasan cosas, se queden allí, entonces se recochan, se molestan, mientras estemos en el grupo, pero ya cuando salimos del grupo es respetar la intimidad y respetar la vida del otro. Porque imagínate, tú sabes toda la situación de conflicto que se vive aquí, que no se puede confiar en nadie. (Mary Cruz, 23 de mayo de 2014, entrevistada por Molina, I., Tumaco)

En cuanto al proceso de creación, la idea general de cada montaje es "pensada" por Norma y Mary Cruz (lideresas del proceso) e inspirada en los casos de la vida real y en lo que conversan o ven que pasa en la ciudad; luego se socializa y se articula colectivamente con la participación de los integrantes del grupo. La creación es ante todo un proceso cooperativo.

Bueno para la toma de decisiones se unen los coordinadores de grupo y empiezan a escribir la obra, a delegar papeles, luego en los 
ensayos se ve si eso va allí o no es así, y ahí ya todos participan, sobre todo en los ensayos se define si las escenas van así o queda mejor al final...Este proceso se demora dos o tres meses, porque normalmente se empieza a ensayar para la semana por la paz y la semana por la paz es en septiembre. (Zulma, 10 de mayo de 2014, entrevistada por Molina, I., Tumaco)

Las obras se alimentan de la vida en la ciudad de Tumaco, de la cotidianidad de los participantes, y de ejercicios de improvisación a partir de los cuales se van dando pistas para pensar una temática o situación específica a partir de la cual se construyen parlamentos, actitudes y se hace el montaje teatral.

Por consiguiente, se puede afirmar que cada montaje es el escenario para exaltar la vida comunitaria, como una invitación a mirar con detenimiento y con una actitud más reflexiva a la cotidianidad, la algarabía de la calle o los espacios públicos, así como a las costumbres ya incorporadas. Es una exaltación de la vida cotidiana, de los ciudadanos de a pie que no figuran normalmente; de los muertos que han sido olvidados y de quienes ya nadie habla, pero también de los vivos que no tienen ningún cargo importante y que aun así se niegan a ser invisibilizados del todo, en las obras se reivindica lo cotidiano, lo colectivo, el saber popular, aquello que tiene que ser explicado a los foráneos, no a los coterráneos de esta costa del pacifico.

Las obras, como se mencionó anteriormente, hacen énfasis en dos aspectos centrales: por un lado, buscan profundizar en las costumbres culturales de la región e indagar en la cultura ancestral afrodescendiente:

Desde lo étnico, de las tradiciones la cultura y todo lo que tiene que ver con la parte de identidad escogemos qué es lo más cercano y qué de la historia de lo que conocemos de la identidad afro se adapta a la actualidad, qué conocemos de nuestros abuelos de nuestros padres o de nuestro pueblo que haya sido semejante o que haya cambiado totalmente a esta época, lo que se ha ido perdiendo cómo rescatarlo. (Karen, 15 de mayo de 2014, entrevistada por Molina, I., Tumaco) 
Por otro lado, se enfatiza en denunciar y visibilizar la situación de violencia a la que se enfrenta la población, la realidad de los y las habitantes de Tumaco, desde la perspectiva de los derechos humanos (leída por los participantes del grupo), por la lectura de su territorio, de lo que escuchan, ven o sienten en los barrios, en las calles, en el colegio. Es un proceso de creación que parte de lo privado y lo público, de la experiencia de los teatreros, en primer lugar, y de los ciudadanos del común, y que se convierte en metáforas, en danzas, en espectáculo.

Todo el tema de los derechos humanos, en la formación hemos ido conociendo los derechos, el tema del conocimiento de la exigibilidad entonces también cómo puede encajar esto con la recuperación de la identidad pero también con la dignificación del ser humano, y todo el tema de conflicto de los casos y los testimonios que conocemos, eso nos permite acercarnos más a la realidad que viven las comunidades, desde los sectores, de los barrios, de las familias, cómo se sienten, qué es lo que están viviendo, a veces uno no se alcanza a imaginar ni a dar cuenta, pero a veces cuando hacemos los ejercicios de contar cómo hemos estado qué ha pasado en determinado tiempo por decir algo en cada 8 o 15 días que no nos hemos visto, eso permite mostrar cosas que ni idea. Entonces todo esto y hacer el ejercicio de contarnos cómo estamos, cómo nos sentimos, de compartirnos, eso también nos ayuda o de cómo están nuestros barrios, nuestros sectores nos va dando esas ideas, como esas pistas de por qué lado queremos enrutar, qué queremos y empezamos a hacer ejercicios de improvisación. (Karen, 15 de mayo de 2014, entrevistada por Molina, I., Tumaco)

Este ejercicio de improvisación resulta fundamental para el proceso de creación, porque es en los ensayos donde las obras van tomando forma, pues se van integrando los diferentes saberes o competencias de los participantes. Es un proceso reflexivo y creativo que surge de la improvisación, del uso del lenguaje corporal, de las conversaciones, de la realidad, de la discusión colectiva.

Así, las obras se nutren de los ejercicios permanentes dentro del grupo, de los encuentros cotidianos, de la integración de saberes, de 
la representación de la cotidianidad de la vida en la ciudad, de las conversaciones, los rumores, las prácticas sociales, de la vida en comunidad. En sus comienzos, el grupo buscaba adaptar obras teatrales a su realidad, pero luego se empezó a incorporar lo que experimentan como habitantes de un territorio específico en un momento determinado, es decir, los montajes están situados temporal y territorialmente.

Esta demarcación histórico-social se encuadra en una realidad de injusticia, que denuncia a través de la experiencia estética la distancia entre lo que la ley establece y lo que experimentan las víctimas, del ejercicio de recordar y olvidar como sustrato de la historia colectiva, de la muerte como práctica que elimina lo político, la vida social, y que determina una forma particular de poder y de orden mediado por la violencia. Por eso se van haciendo pequeños ejercicios de improvisación que no tienen una finalidad específica, pero que recrean diferentes situaciones y que se producen espontáneamente, las mismas que eventualmente pueden incluirse y mostrarse a través de un montaje.

Así de esos pequeños skates, van saliendo las obras, por ejemplo, el de la moto, después nosotros miramos en conjunto, por eso esto es un trabajo de creación colectiva, porque todos miramos y decimos, no, eso no, metámosle esto, no pero acuérdense que en este ensayo hicimos esto o aquello... entonces, antes de cada montaje hacemos una serie de talleres, una serie de ensayos, y de cada ensayo vamos agarrando cositas que nos puedan servir, para el montaje de la obra como tal. (Nohora, 20 de mayo de 2014, entrevistada por Molina, I., Tumaco)

Así, los ejercicios de improvisación cumplen con la intencionalidad de convocar la participación y apropiación de los participantes; también permiten que las obras se adapten o modifiquen a medida que se van presentando, porque siempre habrá elementos que se les puede incorporar y así adaptarse a las circunstancias. Las obras siempre son susceptibles de modificaciones, no son piezas terminadas totalmente. 
Por ejemplo para la gran comarca de la Tonga esa obra sí que la hemos modificado, aún ya luego de hecha, le hemos ido metiendo cosas, porque cada vez que nos vamos a presentar miramos el espacio, el público, qué público tenemos: jóvenes, niños, adultos, así lo vamos modificando, por ejemplo, la gran comarca de la Tonga tiene fragmentos de mi otro yo, tiene fragmentos de como los santos, tiene fragmentos de renacer, y se le han ido metiendo cositas de las otras obras, que al final se ve genial. (Nohora, 20 de mayo de 2014, entrevistada por Molina, I., Tumaco)

El teatro significa para estos jóvenes la posibilidad de nombrar y de resignificar la realidad que viven cotidianamente, de denunciar los efectos devastadores de la violencia para el tejido social de esta comunidad y, lo más importante, sin que su vida corra riesgos; además, con la posibilidad de hacerlo posible sin necesidad de estar habilitados para ello, es decir, sin que medie ningún tipo de estamento municipal, de espacio o de norma que lo permita. Es una posibilidad abierta de argumentar a partir del sentido común, desde la corporalidad, desde un lenguaje metafórico, la gestualidad y la plasticidad de poner en escena sus pensamientos, sus sentimientos, las vivencias particulares y colectivas.

El teatro es una manera de expresarnos, de mostrar lo que sentimos, de sacar todo lo que no queremos, es un espacio donde podemos decir lo que sentimos sin temor a ser rechazados, porque es el momento adecuado de rebeldizarnos (sic) de sacar a la luz muchas cosas que a la gente le da temor decir, por la violencia y por muchos otros factores que influyen. (Zulma, 10 de mayo de 2014, entrevistada por Molina, I., Tumaco)

Es una forma de expresión que está direccionada a visibilizar la violencia, pero que también sirve de puente entre la cruda realidad y una forma diferente de sobrevivir, de resignificar esos hechos lamentables y de ampliar la perspectiva frente a las víctimas y a lo que la violencia produce entre las personas.

Nosotros contamos, no somos como los actores, que ellos trabajan por aprenderse un papel y ya, en cambio nosotros no, nosotros 
trabajamos, aprendemos el papel, lo trabajamos a diario, para que la misma gente pueda transformar la obra. Nosotros trabajamos con la línea del teatro del oprimido, que permite que la comunidad también sea partícipe de las obras, que por ejemplo, hicimos una vez un taller en el que actuábamos, planteábamos una realidad X, entonces después que terminábamos de hacer las presentaciones le decíamos a la gente cómo creen ustedes que están mirando como espectadores, cómo pueden cambiar la realidad, supongamos, entonces no yo prefiero que sea así, entonces no venga actúelo y lo hace como cree usted que es, lo hicimos en un encuentro que hubo en la casa de la cultura, de cómo cree que usted puede cambiar la realidad, entonces la misma gente sale y dice cómo puede ser y también de ahí vamos tomando cositas, que también nos pueden servir para los montajes, entonces yo creo que esto es algo esencial, algo que caracteriza a teatro por la paz. (Nohora, 20 de mayo de 2014, entrevistada por Molina, I., Tumaco)

Así, la apuesta estética de este grupo se enmarca en el teatro del oprimido, donde ser actor surge de la necesidad y el querer de quien actúa, de quien representa una realidad, que es ficción pero que no deja de denunciar y hacer algo por transformar esa situación, al menos en términos cognitivos o de la expresión.

La técnica del teatro del oprimido es una técnica que, uno, se basa en la acción colectiva de muchas personas y, dos, muestra una realidad que dice que para no necesariamente nosotros debemos ser actores para presentar una obra de teatro, que todo parte de la necesidad, del querer, y los oprimidos son a los que nos han violentado, negado nuestros derechos, las víctimas en todos los sentidos, más de los grupos armados, son los más violentados, pero víctimas en todos los sentidos. Nosotros nos ponemos en los zapatos de las víctimas, entonces, nosotros lo que hacemos es mostrar que más allá de lo que pasó hay una víctima que es la que está sufriendo y está afectando, y que es a esa víctima a la que hay que reparar y que es a esa a la que tenemos que proteger también. (Johana, 19 de mayo 2014, entrevistada por Molina, I., Tumaco) 
Siguiendo a Echeverría Reina (2012, p. 40), el teatro del oprimido es una modalidad teatral creada por Augusto Boal en 1971 basada en el teatro político, que retoma la resistencia de Brecht y la pedagogía del oprimido de Paulo Freire. Tiene como propósito transformar al espectador en protagonista de la acción dramática y a través de esta transformación, convocar al espectador a generar acciones reales que conduzcan a la liberación. La técnica del teatro del oprimido ha demostrado su potencialidad educativa, generando acciones colectivas y acción transformadora en diferentes contextos culturales, especialmente en los de opresión e injusticia, pues es ante todo un ejercicio de sensibilización que convoca a la acción no sólo entre los actores sino también entre los espectadores.

Como fruto de esta experiencia, los jóvenes participantes afirman que adoptar a la vida personal algunas de las herramientas aprendidas durante el ejercicio de expresión corporal y mímesis que implica el teatro, sumado a la reflexión permanente en torno a los papeles que interpretan y hasta qué punto yo soy eso que interpreto, o ese a quien yo interpreto es fruto de lo que soy yo, modifica la forma de ver las cosas, pero surgen además diversos aprendizajes que son significativos para los teatreros.

El hecho de que las obras permitan esos espacios de reflexión, esos espacios de análisis, es mucho lo que ayuda, porque uno va creciendo también en su ambiente o en sus relaciones familiares, en sus relaciones de amistad, laboralmente también uno va adquiriendo otras habilidades, otras herramientas, otras metodologías que te pueden ayudar a integrarlas al trabajo y hacer su trabajo con calidad, y no solo eso, sino que también al colaborar uno sigue siendo humano y uno se deshumaniza a veces porque a veces somos tan autómatas en nuestras labores que nos deshumanizamos y deshumanizamos nuestras labores o nuestros trabajos, y eso nos permite sensibilizarnos y también nos permite tomar esas herramientas e integrarlas en todo momento y en todo espacio hacer la situación consciente, y hacer consciencia de que estamos rodeados de personas, de situaciones y que nos preparan también 
para saber cómo enfrentarnos a la vida. (Karen, 2014, 15 de mayo, entrevistada por Molina, I., Tumaco)

Así, los ejercicios de expresión propios del teatro les han servido a estos jóvenes para trabajar con poblaciones similares y adelantar otro tipo de trabajo social en la pastoral o en las comunidades a las que pertenecen. Además, gracias al trabajo intergeneracional y cooperativo que hay en grupo, han podido integrar saberes y compartir experiencias sobre la comunidad, las costumbres, el trabajo o los liderazgos sociales; además, han aprendido a negociar con la diferencia, con los otros, sin acudir a la violencia o replicando las prácticas sociales de la desconfianza y el miedo a la confrontación.

El solo hecho de creer en mí, y de creer que yo no tengo la única palabra, sino que también tengo que escuchar otras versiones y aceptar lo que las personas dicen. [...] El grupo de teatro me ha enseñado que todo tiene una solución, independientemente de cómo lo resuelva, por ejemplo, tenemos alguna dificultad y el en el grupo cada uno trata de darle una solución diferente. (Johana, 19 de mayo de 2014, entrevistada por Molina, I., Tumaco)

Algo muy importante es que dichos ejercicios también les permiten a estos jóvenes expresarse, socializar y compartir sus pensamientos a través del teatro, conscientes de que hace parte de un ejercicio de expresión y confrontación inherente a cada agente, que corresponde a una característica fundamental de los seres sociales y que amplía ámbitos de comunicación. "No me dio miedo, porque el teatro es mi blindaje, y yo estoy haciendo una obra de teatro que es de lo que yo siento y lo que yo vivo, y no estoy haciéndole daño a nadie, entonces miedo no me dio, durante de la presentación nada" (Johana, 19 de mayo de 2014, entrevistada por Molina, I., Tumaco).

El compromiso entonces es mantener la propuesta, continuar visibilizando y trabajando por las víctimas de este sector del país, con la constancia que esto implica, con la responsabilidad de mostrar realidades y reclamar justicia a través de la puesta en escena, de convocar 
reflexión a través de parlamentos y recursos artísticos que vinculan situaciones, agentes, acciones y omisiones.

El reto ahora que se va Norma es mantenerlo y seguirlo fortaleciendo, no es que porque se va Norma hasta ahí nos llegó el proceso. Es también que todos los que nos hemos formado durante el tiempo que llevemos en teatro por la paz tenga esos resultados y esa semilla que quedó sembrada ahora hay que cosecharla y multiplicarla. Estos jóvenes de verdad se apropien y se fortalezcan y que sigan este proceso con otros grupos, otros jóvenes, y multiplicar esa formación y mantener el grupo, no dejar caer el teatro por la paz; sino sostenerlo, mantenerlo y continuar con los procesos de capacitación, de aprendizaje, y también con esa gran misión que tenemos de ser la voz de los que no tienen voz, de romper con el silencio de las víctimas, y no sólo de las directas sino también de las personas que estamos involucradas y a quienes la situación social del conflicto nos afecta. (Karen, 15 de mayo de 2014, entrevistada por Molina, I., Tumaco)

La intencionalidad de estos jóvenes es, en primera medida, hacer sostenible este espacio de expresión y creación que se ha instituido en Tumaco, continuar enriqueciéndolo con montajes que convoquen a la belleza, a la alegría, al recuerdo, a construir memoria y a la acción transformadora. En segunda instancia, es hacer del teatro una oportunidad para que muchos otros jóvenes puedan formarse como líderes sociales en este espacio de expresión y socialización, para continuar con el camino recorrido hasta este punto, no solo en lugares dispuestos para este fin, sino también en escenarios como los colegios, con grupos juveniles del Centro Afro, en las juntas de acción comunal o en encuentros culturales y sociales de la región.

\section{Uno entre mil: el juego consciente}

Uno entre mil ha establecido diferentes mecanismos que refuerzan la razón lúdica que mueve al grupo. Entre ellos se destaca la estrategia denominada El camino del Benjamín, la cual busca que cada participante 
decida recorrer el sendero de su propio camino en busca de convertirse en un Benjamín, es decir, en un foco que irradia su propia luz, "a partir de la explotación felicitaria de su talento" y que puede iluminar-se, pero también iluminar a otros. Este es el propósito del grupo, que cada participante, antes que nada, recorra su propio camino, y así le de vida al camino del grupo. Para eso tiene que hacer una iniciación, que es la posibilidad de detenerse a pensar qué es lo que realmente quiere hacer, y en ese sentido qué puede hacer o modificar en su vida para caminar en el sendero esperado. Es la invitación a iniciar una travesía que empieza individualmente y que se acompaña permanentemente de la ritometodología; es decir, que el rito acompañe todas las actividades del grupo para que, más que acciones, se configuren como momentos rituales que tienen un propósito para cada participante y para el grupo en general. En la medida en que cada agente decida caminar, irá alimentando al grupo con sus propios descubrimientos internos y también de las relaciones que lo sostienen.

Así, cada actividad tiene unas formas, unos propósitos, unas herramientas y unos descubrimientos por hacer, en función de alimentar colectiva e individualmente la trayectoria del grupo. El juego es el centro de toda actividad, el juego en clave espiritual, no es jugar por jugar, es esperar transformaciones de cada sesión o encuentro, es concebir la vida como un espacio lúdico donde la magia florece permanentemente.

Para tal fin, el grupo ha establecido una serie de agenciamientos discursivos que dotan de sentido las acciones que emprenden. Uno de ellos tiene que ver con la idea de parar, de detenerse un momento, de dejar el afán, de convocar a que cada participante se detenga en la carrera de velocidades que caracteriza el presente y pare a jugar, para encontrar otro ritmo, para desplegar otro tipo de relaciones con el entorno, con cada uno, con los otros participantes. El interés hacia la lentitud está relacionado con generar en los participantes una actitud reflexiva de sí mismo, de aprehender de una forma diferente el presente y el mundo, de sentir la cotidianidad con una intensidad diferente, que posibilite ante todo un ejercicio de conciencia del momento presente, para proponer a través de este un horizonte de transformación y de significación hacia la vida misma. Como diría Raymundo Mier Garza (2012): "La lentitud traslada esa reflexión a un dominio de la 
experiencia que compromete no sólo al cuerpo sino a las propias formas de vida, a las modalidades de la acción. Se transfigura en una gravitación de los cuerpos y un diálogo inquietante con el entorno" (p.150).

A partir de la invitación permanente del grupo a hacer un pare, se propicia en el participante un momento diferente para pensar-se y reflexionar sobre su hacer, pero también sobre su relación con el entorno inmediato, en sus relaciones, en su lugar de trabajo, en su vida privada o en su ciudad. Para el grupo, hacer una pausa es una excusa perfecta para reflexionar y actuar, para producir situaciones inéditas, momentos alternativos a los que ofrece la cotidianidad, todo esto a través del juego. Este último se consolida como una metáfora que le permite al grupo construir un espacio de relación diferente, mediado por el disfrute, por la posibilidad de intercambio lúdico que favorece la distención, la alegría, el gozo y la creatividad.

El juego se convierte en un dispositivo que apela a una racionalidad diferente, mediada por los sentidos, por el disfrute, por una percepción diferente del espacio-tiempo, lo cual se vincula perfectamente a la concepción de experiencia estética, por cuanto se configura como una actividad placentera, rítmica, lúdica y armoniosa; pero sobre todo por su capacidad implícita de provocación o creación de realidades inéditas, que implican en diferentes ámbitos a los participantes y que se configura como una forma de construir experiencias, aprendizajes y, en el caso de Uno entre mil, horizontes de sentido.

Para Huizinga (2000), el juego es una actividad fundamental en el desarrollo de la cultura, dado su carácter lúdico, que cumple con unas funciones determinantes para las sociedades tanto de memoria y aprendizaje, como de valores, establecimiento de reglas; también es una posibilidad de acercarse al conocimiento de lo sagrado. Para este historiador, el juego responde a unas características que bien tienen que ver con la concepción que propone Uno entre mil:

- El juego es una expresión de la libertad, porque es una experiencia genuina que siempre es una elección. Los participantes de Uno entre mil decidieron parar el afán cotidiano para jugarse la vida, para dedicarse tiempo, para compartir tiempo con otros, para hacer cosas que normalmente no hacen y que 
gracias al juego tienen sentido, no solo en el grupo, sino también como práctica felicitaria en la vida de cada participante. Esta es una manifestación autónoma del grupo y de los participantes, asumir el juego como motor de experiencia y de identidad de Uno entre mil.

- El juego es opuesto a la vida cotidiana, es la vida "como si", entre paréntesis; es un tiempo diferente a la cotidianidad y fugacidad de la existencia humana. Como Apunta Ríos (2009), "el juego es un presente pleno de sentido en donde el tiempo es suspendido" (p. 75). Es decir, se ha consolidado como la forma más oportuna de asumir y entender el presente; es una elección consciente hacia el jugar como una oportunidad inédita de encantar el presente, de operar en él atendiendo al hacer con un criterio lúdico y de armonía que favorece la creación colectiva.

- El juego goza de un carácter desinteresado en contraste con la vida cotidiana. De esta manera, se consolida como un acto intencional, absolutamente consciente, que busca reivindicar el tiempo del juego como un espacio propicio para crear y compartir experiencias singulares y colectivas, que se inscriben en una lógica opuesta a la que exige la modernidad, pues están desprovistas de control y de productividad en el sentido laboral o económico; sin embargo, permiten que la concentración se localice en el proceso mismo, no en el resultado final o en los posibles resultados. Para el grupo se consolida como una experiencia única e irrepetible, validada en sí misma, es decir, dotada de sentido y que sirve además como apertura de horizontes de significación frente al grupo, actividades futuras o planes de acción.

- Es un complemento de la vida misma, que genera reflexiones pertinentes para el momento que experimenta el grupo y cada participante. Se convierte en un elemento fundamental para todas las actividades que organiza Uno entre mil y es la apertura 
a cada aparición, pero también es la oportunidad siempre consciente de enriquecer el hacer, de iluminar creativa y lúdicamente cualquier proyecto, cualquier acción, cualquier encuentro. Es un dispositivo que provoca sensaciones, reflexiones, aprendizajes y nuevas experiencias.

Además, el juego se consolidó como un elemento mágico que articula al grupo, que le permite a los participantes adentrarse en una forma particular de aprendizaje, de autoconocimiento y de ritual, como una forma simbólica que permite comprender algunos contenidos, en este caso sobre el presente y la trama de relaciones que constituyen la vida de los participantes, pero también de manifestar creencias o formas particulares de asumir la fe, las prácticas religiosas y de concebir el universo en su complejidad.

El juego, al igual que el ritual, establece unos límites y unas formas específicas del hacer, que dotan de sentido a la experiencia y que resignifican la realidad de los participantes, así que para Uno entre mil el cruce entre estos dos elementos es fundamental para entender su sentido de pertenencia.

En función de lo anterior, el grupo ha establecido al juego como un dispositivo, pero también como matriz que orienta la acción. Es decir, todas las actividades que se desarrollan en Uno entre mil tienen como eje articulador el juego, y cada espacio o ámbito de acción es un nivel de juego, que se organiza por krakens, "que son grupos conformados por varios lualentos y un Benjamín, conectados por empatía, que construyen proyectos de interacción mediante el método de Lúdica Patagógica" (Uno entre mil, 2015); $;^{5}$ o sea, por equipos que tienen unos intereses particulares y que se articulan lúdicamente en torno al acto de jugar, en el cual cada participante es el protagonista por excelencia, pues este es un ejercicio en el que se privilegia a la experiencia como una práctica educativa esencial y significativa, sobre todo para la vida de cada participante. Por ejemplo, hasta el momento de conversación con el grupo (primer semestre de 2014) existían los siguientes krakens:

5 Información obtenida de la página web del grupo: www.unoentre1000.com, recuperada en mayo de 2015. 
Kraken Liga del ocio - ocupaciones felicitarias: somos un grupo de personas (Lualentos) en conexión con el ocio que exploramos la ciencia, el arte y el deporte como una posibilidad para jugarse la vida con la intención de propiciar espacios para asumir la existencia como Arte-Sano para la felicidad. Todas estas ocupaciones felicitarias se llevan a cabo en expediciones de ocio, teniendo como metodología la lúdica patagógica, donde el vehículo es el cuerpo, responsable de la memoria del ser humano. En este kraken se cuenta con unos k-talleres, patalleres y expediciones específicas.

\section{$[\ldots]$}

Kraken entremundos - conectamos la imaginación: somos un grupo de docentes exploradores de la web y sus mundos virtuales, que investigamos sobre la incorporación de diferentes tecnologías de la información y la educación en el aula para favorecer los procesos de enseñanza y aprendizaje, especialmente en lo que se relaciona con la naturaleza, el desarrollo y uso de la inteligencia y la creatividad humana. (Uno entre Mil, (2015)

Este espacio de acción es el que está vinculado a las comunicaciones mediadas, para ampliar y diversificar los mensajes que por ahí surgen, para generar otros vínculos, conectar a otros y socializar de alguna forma los aprendizajes construidos en el grupo.

Nos hemos dado cuenta que hay un mundo paralelo a este sistema de caos, hay un mundo que cogió mucha fuerza y es el mundo virtual, entonces hoy las relaciones son virtuales, entonces vos hasta conseguís pareja virtualmente, hacés el amor virtualmente, todo lo hacés a través del Facebook o lo virtual, entonces se crea otro mundo, entonces nosotros creamos una plataforma que estamos en proceso de desarrollar muchas de las cosas que son de ahí, ahí está con los dedos porque es digital, técnicas para el inmigrante digital, o sea, nosotros tenemos la manera, hemos creado la manera para que las personas se relacionen con ese mundo virtual pero 
desde lo espiritual, o sea, para que entiendan eso para qué les puede servir, para que entiendan qué es una red, qué es estar en una matriz, entonces ahí hay una cantidad de personas, hay ingenieros que dicen yo me voy por ese lado, eso es, yo quiero hacer eso, yo quiero enseñarle a la gente a que sea consciente de qué es lo que hace, de lo que hace en ese mundo virtual, entonces encuentra su labor felicitaría aquí, otros se encargan de la liga del ocio, otros la encuentran en Milagros, otros en espíritu verde, y así [...] (Diana, 29 de marzo de 2014, entrevistada por Molina, I., Medellín)

Kraken sanjuanés - hágalo usted mismo: la buena vida se encuentra también en la alimentación. Por eso, a través del kraken San Juanés proponemos el aprendizaje, el disfrute y el compartir de la comida como una experiencia que nutre no solo al cuerpo sino también al espíritu. Katar es nuestra actividad principal, nos dedicamos a encontrar el sabor de los alimentos, conocer de dónde provienen, cómo se producen, cómo se preparan, cómo se degustan. Vivimos la alimentación desde el sentir. En este kraken se hacen Katas de cerveza, de vinos y cenas. (Uno entre Mil, 2015)

Este espacio está vinculado a la soberanía alimentaria asociada a huertas, a la elaboración artesanal de cerveza, vinos, tortas, "todo concebido en talleres y en esa relación de la buena alimentación, o de hacer con tus manos tu alimento y de forma creativa" (Julián y Natalia, 30 de marzo de 2014, entrevistados por Molina, I., Medellín); de este modo, se fomenta un tipo de autonomía alimentaria, a partir del consumo y producción de alimentos, y de activar la creatividad como ámbito inicial donde se juega la vida.

Para nosotros qué es lo contrario del consumismo, el animismo, anímese a entender qué es lo que realmente usted necesita en la vida, entonces aparece algo que nosotros llamamos: Milagros, los milagros para nosotros es todo el tema de soberanía alimentaria: tómeselo que es bendito, asanas que sanan. (Diana, 29 de marzo de 2014, entrevistada por Molina, I., Medellín) 
Kraken espíritu verde - por una conciencia EcoLógica: Somos poetas de la existencia y de la vida, creemos en la lecturaleza como forma de interpretación de las señales de la vida en las plantas y en las relaciones que establecemos, en la forma como habitamos. Nos conectamos con la tierra para ser conscientes del impacto que tenemos en la trama de la vida, para pensar nuestra huella ecológica sobre el planeta y transformarla. Nuestra ocupación felicitaria consiste en ponernos verdes de la felicidad por amar la Madre Tierra, rastrear nuestras huellas y vivir una patafísica de las plantas y una alquimia de nuestro habitar rizomático. En este kraken hay unos k-talleres de sensibilización, patalleres de profundización y excursiones. (Uno entre Mil, 2015)

Este espacio es muy importante para el grupo, pues se busca a través de la ritometodología hacer de la vida un rito, o hacer ritos para vivir en conexión directa con el espíritu de la vida: el espíritu de la naturaleza.

Tenemos todo lo que tiene que ver con el tema ambiental, con el tema de cómo yo conecto mi energía en lo que soy como ser humano con esa tierra, con esos elementales, agua, aire, fuego, que yo empiezo a entender que yo soy parte de un todo y ese todo tiene una historia, tiene una memoria, y esa memoria yo la encuentro aquí, en mis archivos acacios, que esa memoria está aquí guardada y yo no la he podido encontrar porque siempre me enseñaron que tenía que mirar hacia afuera, yo tenía que ver afuera e ir a buscar la verdad en otros espacios, entonces aquí es donde me doy cuenta en todos estos k-talleres de espíritu verde que la verdad no está afuera, la verdad está acá adentro, entonces empiezo a trabajar eso [...] En este espacio hace parte la ExpediZión Aburrá, viaje Extremo, toke tierra y más. (Diana, 29 de marzo de 2014, entrevistada por Molina, I., Medellín)

Las premisas que orientan este kraken tienen que ver con recorrer o caminar el territorio del valle de Aburrá, como una forma de empoderarse, de conocer cómo está conformado, qué tipo de ecosistemas habitan esta parte de Colombia, y también para fortalecer esa relación 
entre la vida humana en correspondencia con la vida de la tierra, como una posibilidad de conocimiento y reflexión frente a los usos de esta última, tratando de comprender un poco más las relaciones de la vida en el Valle de Aburrá.

Como se puede observar, el campo de acción de cada kraken es muy amplio y permite que este se transforme y nutra en función de los participantes de cada grupo; de ahí que la oferta de k-talleres, patalleres y expediciones se transforme continuamente.

Con lo anterior, también se puede entender un poco el tipo de vínculos que establecen con su acción entre diferentes ámbitos o esferas de lo humano, y esto se da gracias al juego como eje articulador de sentidos. Por ejemplo, en cada uno de los escenarios creado por el grupo, hay una correspondencia explícita de búsqueda de sentido del hacer a partir de lo ancestral, de la ritualidad, como ejercicio de memoria de las tradiciones originarias que le dan prioridad a otros valores, a otras formas de comprender el presente, la relación con la naturaleza y la vida humana.

Asimismo, en cada aparición siempre hay un interés por apelar a la búsqueda de la belleza, no en el sentido contemporáneo de vanidad, sino de comprensión del misterio o milagro de cada encuentro, de la oportunidad de disfrutar sabores, del compartir espontáneo entre seres que produce experiencias placenteras; es la permanencia del disfrute como base de la acción y esta intención se traspone a la vida cotidiana de los participantes, los cuales incorporan esta significación a sus propias relaciones con otros y con el mundo.

Esta intención latente en el grupo corresponde a un interés de creación de ámbitos, espacios o momentos que les permita a los participantes hacer parte de vivencias que generan aprendizajes que han surgido de la reflexión en torno a la experiencia producida en el juego como ritual, que producen saberes aplicables a la vida cotidiana y a las posibles formas de relación con otros y con el mundo en general. Asimismo, a cultivar formas y sentidos construidos colectivamente en el hacer, en la experiencia creativa, sensorial y única que produce al participar de cada aparición. Esto significa que el grupo está configurando colectivamente otras maneras de comprender y del hacer a partir de sus propios intereses en una ciudad como Medellín. 
Además, el grupo ha establecido algunas estrategias de enunciación y argumentación para definir el recorrido, los espacios y las formas de participar en la experiencia de Uno entre mil. Una de esas estrategias es definir al camino del Benjamín como el proceso que cada participante adelanta en el grupo. Este es el recorrido que se establece dentro del grupo y que se asume como una norma del juego, para así superar fases o momentos, todo en función de lograr la conexión con cada participante y su ocupación felicitaria. Esta la forma como alguien se activa en el grupo, haciendo - en función de su interés- el camino que quiere seguir. Es la sincronización que tiene cada integrante con su interés personal, dependiendo de eso se logra vincular creativa y activamente en el grupo a través de los Krakens.

El camino del Benjamín es un proceso personal, que se alimenta de la relación con otros participantes, pero también de la relación que se establece con el mundo, con la naturaleza, con las medicinas, con sus propósitos y con las metodologías dispuestas en el grupo.

Depende de la conexión que tengas tú contigo mismo, depende de si ya encontraste tu labor felicitaria, si la encontraste entonces ya vas en otra dirección porque ya vas en la dirección de ser un benjamín que es capaz de conectar su luz y hacer que otros se conecten desde su luz, eso es el benjamín. (Diana, 29 de marzo de 2014, entrevistada por Molina, I., Medellín)

El benjamín es una metáfora que alumbra el camino; esta es una característica sobresaliente de Uno entre mil, como un recurso que determina la posibilidad de aprovechar los múltiples sentidos de las palabras para renombrar la realidad. El camino del Benjamín es la metáfora que conecta mundos de sentido que siguen reelaborándose en el juego y que le dan razón de ser a la participación individual y grupal.

Ese camino es también un sendero de aprendizajes; el juego es una forma de recordar y de aprender cosas que tal vez habíamos olvidado o que no sabíamos y que son vitales para la existencia de cada uno. Es también un camino de iniciación, una forma específica de crear saberes o conocimientos que son una forma de poder. 
Para el grupo, la importancia radica en reconocer que ese poder se crea, se anima, se reproduce en la medida en que cada uno es consciente de él, pero no solo basta con esa conciencia, hay que activarlo y enseñarlo a otros. Solo en la posibilidad de aprender con otros, enseñando o desaprendiendo, es posible cambiar la vida de cada uno, que es por excelencia el lugar inicial de ese poder.

Pero esta construcción de saber-poder no es posible si no se parte del interés real de cada participante. Para esto, lo primero que se hace al entrar a Uno entre mil es crear un nombre patagógico, que busca dejar salir al personaje que sinceramente cada uno quiere ser, que ya habita en nosotros y al que hay que activar en los espacios donde se participa. Este ejercicio es una creación de realidades infinitas, es una puesta en escena, de ritualizar cada encuentro.

Esto se puede entender también como un recurso simbólico de enunciación importante para el grupo, porque autodenominarse con un nombre patagógico es permitir a cada participante olvidar un poco quién es o debe ser en el mundo cotidiano, es tener la posibilidad de asumir un rol acorde a la expectativa de cada uno, no a lo que socialmente se impone. Esto se consolida a partir de la experiencia y del autoconocimiento que se produce a través de la participación en diferentes apariciones o eventos. El jugar se consolida en una oportunidad de reflexión de sí mismo y del entorno donde cada participante se ubica. Esta es una dislocación que el grupo está produciendo, en el sentido de que el primer espacio de trabajo es la identidad, la subjetividad, el aprendizaje de sí mismo, a partir de una exploración consciente de sí, que se consolida en el acto de jugar, de participar desinteresadamente en un espacio de ocio, de compartir con otros; aparentemente no se busca otra ganancia más allá de la diversión y de reconocer en la vida propia la aventura de la incertidumbre que implica el jugar.

En función de lo anterior, Uno entre mil ha establecido diferentes espacios, que parten de la idea de probar como principio esencial para jugar: "Se llaman k-talleres porque empiezas a catar, a probar, a identificar, ve este tan bacano, este tan bacano, entonces acá nosotros tenemos muchos semilleros para que cates, y los hemos estructurado porque van en distintas líneas” (Diana, 29 de marzo de 2014, entrevistada por Molina, I., Medellín). 
Estos k-talleres hacen parte de lo que se ha denominado la liga del ocio, que privilegia la creatividad a través del juego. Esta relación es fundamental, es la base del grupo. No hay creación sin juego, o sea, sin que sea divertido, lúdico. Es devolverle la magia a la vida misma y a la relación con el entorno y con los otros, a través del juego, como dinamizador o provocador de realidades diferentes, de magia, dada su condición de acontecimiento irrepetible. Como fruto de esa intención, hay una dislocación explícita con el imaginario frente al juego y a la ocupación del tiempo, en oposición a la condición de productividad económica implícita en la modernidad, que elimina o condiciona el uso del tiempo libre y que sanciona, especialmente en la condición juvenil, las actividades que pierden de vista el resultado o la productividad en la sociedad moderna.

Nos enseñaron que el ocio es pereza y que la pereza es mala y ¿parar para qué? Usted tiene es que salir corriendo a ver cómo va a sobrevivir. No, aquí decimos en la liga del ocio usted tiene la posibilidad de entender realmente qué es el ocio creativo, y como para nosotros el juego es la manera, usted entonces empieza a entender que es en el juego como su creatividad se va ampliando; entonces aquí hay una serie de k-talleres, que nosotros trabajamos para que usted vaya desarrollando eso que este sistema le limitó, que es la creatividad... Para usted aprender a ser creativo tiene que jugar, tiene que estar tranquilo, y tiene que vivir más tranquilo, y el juego permite eso, el juego le permite desconectarse de la realidad e imaginar una realidad que usted quiere. (Diana, 29 de marzo de 2014, entrevistada por Molina, I., Medellín)

Las oportunidades de encuentro y de juego se convierten en espacios de exploración individual y colectiva en función del grupo mismo. Uno entre mil ha establecido diferentes espacios donde cada participante puede explorar sus intereses; uno de estos es el laboratorio de juguetes y objetos bizarros. Este es el espacio "formal” para construir colectivamente herramientas que faciliten y contribuyan a cada kraken o proyecto. Como su nombre lo indica, su intención es crear juguetes (herramientas) que sirvan para facilitar el juego en cada espacio 
o k-taller. "El laboratorio de juguetes y objetos bizarros es cómo se puede poner juguetes en cada espacio, que es una de las ideas, que cada viaje o cada ExpediZión tenga su juguete" (Julián y Natalia, 30 de marzo de 2014, entrevistados por Molina, I., Medellín). Es decir, el proceso de creación también incluye el ámbito de lo práctico, de las herramientas de las que se valen para llegarle a más gente, o para jugar en cada ExpediZión.

La Eskuela de Artes y ocupaciones felicitarias es otro espacio que se viene trabajando desde hace dos años y que busca, a partir del trabajo con niños y niñas, gestionar el talento de los participantes a través del juego:

La escuela de artes siempre me ha parecido el escenario donde se comparte lo que hemos aprendido, ahora lo veo como un escenario para los niños, para que los niños jueguen a la búsqueda de talento, pero la búsqueda de talento es lo que nosotros estamos sintiendo, cuál es el talento y cómo lo estamos o cómo lo gestionamos”. (Julián y Natalia, 30 de marzo de 2014, entrevistados por Molina, I., Medellín)

Recogiendo lo anterior, cada una de las estrategias o recursos que ha construido el grupo da cuenta de un interés explícito por tramitar su antagonismo hacia la lógica de la modernidad imperante, por eso cada una de las apariciones o eventos que se programa mantiene como interés hacer del encuentro colectivo una posibilidad de acción lúdica consciente, en la cual los lazos de confianza y cooperación se fortalecen, se articulan propositivamente para planear otros espacios o actividades que permitan ampliar el nivel de acción de cada participante. De ahí que cada kraken defina unas metas, unos grupos poblacionales diferentes, que se articulan reflexiva y lúdicamente entre ellos; esto genera apariciones cargadas de sentido para las comunidades donde operan y para los participantes implicados.

En función de esto, el grupo produce unas cadenas significantes que se van articulando a los ámbitos donde los participantes tienen injerencia; inicialmente dentro del grupo, pero también en las redes de relaciones en las que participan cada uno de los Benjamines o lualentos. 
Así es como la ritometodología, la lógica patafísica, el juego y las medicinas que acompañan esta experiencia se van articulando a los universos de sentido donde participan estos jóvenes, y así se configura una perspectiva de acción y de subjetividad que se anuda a los aprendizajes, hallazgos, saberes y a las prácticas que en Uno entre mil se va construyendo. Con esto no me refiero únicamente al campo de lo discursivo, de la inclusión de estos términos y aprendizajes, sino también al campo de lo subjetivo y de la práctica, porque al poner en perspectiva la experiencia construida en el grupo con otro tipo de organizaciones o grupos a los que se vinculan estos jóvenes, se va perfilando una forma particular de concebir las relaciones sociales, de inclusión en el ámbito de lo público, de ser en lo privado, que se relaciona con una vivencia permanente en el aquí y en el ahora que redimensiona todo lo demás y, que establece otro tipo de vínculos sociales, unos más atentos al disfrute, al proceso más que a los productos, a comprender un poco más la relación hombre-naturaleza, hombre-hombre, hombre-todo lo demás. El hacer parte de la experiencia de Uno entre mil configura en los participantes una perspectiva de vida diferente a la que se ofrece en este siglo, y esos aprendizajes o puntos de vista diferentes son los que se van articulando al mundo de sentido donde existen los participantes; estos a su vez van articulándolo en su práctica cotidiana al imaginario de ser joven, de hacer parte de una sociedad como la paisa.

Todas estas estrategias del grupo se configuran para hacer de la vida un juego, en el cual se ritualiza la existencia, a través del compartir y los aprendizajes que cada participante va adquiriendo a medida que camina. El juego es la luz que ilumina esa búsqueda espiritual, pero también esa búsqueda de vida. Estas experiencias se configuran para hacer consciente el desvío por el que transita cada uno y si decide o no corregirlo.

Por eso se hace hincapié permanentemente en reconocer que en este juego lo que se busca es alcanzar la luz, y al estar encendido por asumir el camino de iniciación espiritual que emprendió con Uno entre mil, es necesario actuar en consecuencia, ser coherente; reconocer el poder que reside en cada uno y actuar en consecuencia.

Cada una de las apariciones o espacios del jugar amplían las cacerías que cada participante hace con lo que vive en Uno entre mil. Son 
muchos aprendizajes que dan espejos, lecciones y opciones de cambiar lo que hay que cambiar en la vida de cada uno, en la realidad, a partir del juego y del compartir con alegría. Es un permanente ejercicio de reflexión y aprendizaje a partir de encuentros lúdicos.

Por eso el grupo le ofrece al participante una variedad de espacios donde este pueda fortalecer aprendizajes y permitirse crear desde sus propios intereses. Así, se propende hacia un ejercicio de autonomía reflexiva respecto a dónde sembrar la semilla del trabajo de cada uno, ¿dónde puedo ser más fértil?, es la pregunta que acompaña el quehacer de los que deciden participar y vincularse a alguno de estos espacios. El juego se convierte en el dispositivo a partir del cual se estructuran las relaciones y los sentidos dentro del grupo. "Lo que más ha conectado a la gente, además de muchas otras cosas es la medicina, porque nosotros decimos que la medicina de nosotros es el juego" (Julián y Natalia, 30 de marzo de 2014, entrevistados por Molina, I., Medellín).

Uno de los recursos que está vigente en el grupo es el uso de “juguetes" en cada encuentro. Para esto, no solo basta con emplear los existentes, sino también resignificar su uso y lógica. La creación tanto de juguetes, como de actividades es parte de un proceso de descubrimiento y reflexión personal sobre el talento de cada uno; es parte de un proceso de crecimiento compartido, porque no es solo la organización la que se beneficia, también los participantes, que logran articular sus intereses o búsquedas personales en concordancia con la idea del juego que propone Uno entre mil.

De esta manera, se establecen relaciones entre los participantes, pero también con los juguetes a partir del sentido que estos adquieren en el proceso de cada uno; por ejemplo, el juego del ego, el cual se vale de un artefacto y tiene unas formas de concretarse, pero este juguete lleva implícito un proceso de reflexión aplicado a la vida cotidiana que le confiere sentido, el cual se va resignificando permanentemente con su uso y apropiación en la vida de cada uno de los jugadores. Otro ejemplo es el "apagamentes": "el apagamentes salió de M, es su creación, ya nosotros le hemos ido dando la conceptualización y ha sido parte de un descubrimiento suyo, saber que él es muy talentoso" (Julián y Natalia, 30 de marzo de 2014 de 2014, entrevistados por Molina, I., Medellín). 
La idea de crear juguetes es materializar de una forma específica los aprendizajes que se han ido produciendo en las diferentes actividades, pero también prevalece la idea de crear o mantener una relación con ese juguete; es decir, se articula a una configuración subjetiva vinculada a ese dispositivo, y que todo el tiempo está sintonizándose con el recorrido que cada participante está realizando, con ese proceso de crecimiento interior que cada agente va elaborando al participar en Uno entre mil.

Recapitulando todo lo anterior, el uso de este tipo de juguetes, el tipo de prácticas o rituales que se producen en el grupo, el tipo de lógica con la que se entiende y hechiza la realidad son la estrategia con la que Uno entre mil problematiza la realidad frente a los siguientes aspectos:

- La velocidad, el afán de productividad que media las relaciones sociales, los afectos, el cuerpo con sus enfermedades, los pensamientos, los sentimientos y la vida misma. La pregunta que subyace es: ¿producir qué?, ¿para qué?, ¿para quién?

- Problematizar la relación entre hombre y naturaleza, desde la perspectiva del desarrollo industrial y económico como única realidad posible. El retorno a las medicinas, a los conocimientos y saberes ancestrales de los pueblos originarios les permite a los jóvenes de Uno entre mil asumir otra perspectiva en este aspecto, construir conjuntamente otras maneras, otras prioridades, otras posibilidades de relación que no se fundamenten en la destrucción y el consumo sin responsabilidad. La intención de caminar los cerros de Medellín (en la ExpediZión Aburrá) es el primer eslabón en la construcción de vínculos y saberes sobre el territorio.

- Problematizar la forma como se concibe lo humano, la función del hombre, de cómo se perdió la magia del crear, del creer, del cambiar, de encontrar sentido a lo básico, a la palabra, al hacer-se consciente. Es una crítica reflexiva y permanente a la mecanización de los afectos, de los sentidos, a la deshumanización 
de los vínculos, de los sentimientos, de lo que nos constituye como seres senti-pensantes.

En lo que tiene que ver con el proceso particular de creación, se puede inferir que estos jóvenes son ante todo agentes de cambio, conscientes de su potencial, pues comprenden claramente que en su ejercicio de autonomía y de creación de realidades, están configurando un complejo tejido de significaciones de todo orden. No solamente apelan a una práctica discursiva particular, que resignifica palabras y conceptos, sino también a prácticas lúdicas que invocan la posibilidad de despertar la creatividad, desde una perspectiva de ritualización, que les confiere una implicación diferente a los eventos programados en el interior del grupo, pues están dotados de una conciencia reflexiva en torno al hacer que produce unas valoraciones significativas para los participantes. Esto desborda el ámbito de lo privado, pues activa un tipo de sujeto diferente, uno que es consciente de que su acción, por pequeña que sea, tiene implicaciones directas en la vida de otros, y por lo tanto estas acciones cobran una importancia por cuanto se ubican espacial y temporalmente.

Por otra parte, el proceso de creación dentro del grupo es un proceso autónomo y se nutre de la intención e intensidad con la que participan los líderes en cada kraken; por lo tanto, surge frecuentemente y no hay reglas para esa construcción, justamente por la amplitud que brinda el juego, pues no es rígido, no tiene una direccionalidad específica, todo puede suceder. En este juego no se acota la incertidumbre, se potencia.

Así, los aprendizajes se van configurando con la experiencia y con las iniciativas de los participantes; por ejemplo, la ExpediZión Aburrá, que tiene una intención espiritual de articulación de la vida de cada caminante con la vida en su conjunto y aprender de los cerros que contienen la ciudad, conocer y comprender los ecosistemas que ahí existen.

La ExpediZión Aburrá, que actualmente se hace una vez al mes, surgió como una iniciativa de caminar la palabra, caminar desde la experiencia particular por el territorio colectivo, movido por el interés de conocer el espacio que se denomina el Valle de Aburrá, y que dota de identidad a la mayoría de los participantes, pero que a la vez resulta 
extraño y hasta ajeno. Esta actividad es muy importante para el grupo, pues convoca a otras personas que, aunque no hacen parte del grupo, también tienen el interés por conocer el territorio que habitan, comparten experiencias, construyen vínculos con otras organizaciones, con otros ecosistemas, con los elementos, con otro Medellín; es un laboratorio de saberes, caminos, nuevos vínculos y posibilidades de acción.

Actividades como la ExpediZión Aburrá dan cuenta de un interés notable en las prácticas cotidianas de Uno entre mil por renombrar la realidad que circunscribe al grupo, es decir, apelar a un régimen de significación que busca el reencantamiento de palabras, de significados, de convocar en el lenguaje también una posibilidad de dotar nuevamente de sentido a cada práctica, cada juego, cada circunstancia, herramienta o espacio que surge en la experiencia grupal. Por eso el grupo ha posicionado la idea de crear palabras o cruzar significados con las ya existentes; esto con el ánimo de invocar en la palabra y el nombrar la magia del existir, es decir, lo que se nombra existe, y al nombrar se convocan no solo las características de algo, sino también se evoca su espíritu, o intención implícita en una acción o en un espacio. Así, para Uno entre mil las palabras encantan, producen realidades, tienen implícita una fuerza que permite recordar, evocar, renovar o estimular el presente, por eso hay muchos nombres, muchas palabras trasmutadas o compuestas que tienen sentido en el mundo del juego que proponen estos jóvenes. A lo largo de este apartado se pueden encontrar y en el contexto del grupo se entiende el sentido que producen; es esta una forma particular que han mantenido y que se convierte en un sello de su práctica estética.

La apuesta estética de uno entre mil reside en la reivindicación del juego como una herramienta, como discurso, como fin, pero también como medio que dinamiza el camino que cada quien quiere recorrer. Así, el juego desborda al grupo y se convierte en el juego de la vida, incorporándose a las prácticas cotidianas o colectivas; además, haciendo parte de la forma de concebir la vida para cada uno de sus integrantes. Entonces es una visión compleja de la cotidianidad, que da sentido a la organización y a muchos de los que participan en ella.

El juego en Uno entre mil es también un ámbito de encuentro y de negociación con el otro, porque solo así se puede producir un ambiente 
de creatividad, de alegría, del compartir como experiencia de juego, donde se asumen unos roles y se busca principalmente divertirse.

Llegar al lugar al que TODOS quieren llegar requiere respeto por el ritmo de cada UNO, en unoentre1000 no se tiene afán, todos juegan, crean, aman; y en esa com(ún)ión se generan oportunidades y posibilidades para el "nosOTROS”, es decir, para quienes nos rodean. (Uno entre mil, 2015)

Por eso se definen roles al empezar a jugar o participar en el grupo, primero con el personaje que cada uno quiere, pero también al recorrer el camino del Benjamín se establecen reglas que dinamizan el juego. En un primer momento el que llega es un nacho, que empieza a caminar y cuando se esoteriza pasa a ser lualento, y su fin es convertirse en un Benjamín, es decir, en un ser con talento que se conecta e ilumina con otros. Pero para este proceso es necesario participar en k-talleres o experiencias sensoriales que van generando aprendizajes y fortaleciendo el talento de cada participante, lo que contribuye activamente a generar nuevas expediciones o aportar a las existentes.

Las expediciones es donde se gestionan los talentos. El escenario donde se pone en movimiento lo que ya se sabe que se tiene. Por eso se entra en el momento de posibilitar el intercambio (talento como moneda en Grecia y Roma...un niño o niña con talento es un sujeto con posibilidad de activarse en un sistema de intercambio) es un paradigma de economía diferente. El talento puesto en comunidad. (Uno entre mil, 2015)

En últimas, es activar esa concepción del juego que produce otras realidades, a partir de la relación con el entorno en conjunción con las habilidades y destrezas de los participantes. Un ejemplo claro de esto es la Eskuela de Artes y Ocupaciones Felicitarias, que es un espacio de trabajo con niños y niñas de la ciudad que busca generar experiencias lúdicas que promuevan en los participantes descubrir los talentos que cada quien posee para fortalecerlos a través del juego. "Es un escenario para descubrir ese territorio de armonía que son los talentos. Quien 
descubra su talento, su poder personal y lo fortalezca puede ocuparse gozosamente" (Uno entre mil, 2015).

Para esto, la Eskuela de Artes y Ocupaciones Felicitarias ha adelantado actividades como festivales, $\mathrm{k}$-talleres con niños de sectores vulnerables, k-talleres en parques de la ciudad o en instituciones educativas. Así que en Uno entre mil no solo se busca hacer un trabajo dentro del grupo, sino también trasladarlo a otros sectores de la población de la ciudad, en este caso, niños y niñas de Medellín.

Otro k-taller que se conecta con lo anterior es el de "Leer, tejer y hacer memoria, un espacio que nos recuerda que 'somos palabra'", asunto que implica reconocernos en un tejido lúdiko donde circulan los conocimientos de la tradición, cuando lo primordial era LA PALABRA. Resultado: Tejo el cuerpo del kit de la impecabilidad. Conozco los acuerdos del Juego Del'EGO" (Uno entre mil, 2015).

Estos espacios hacen parte de aprendizajes propios (que han desarrollado algunos participantes), que se ponen al servicio de la comunidad Uno entre mil, para que se vaya materializando el interés de incorporar a la vida propia el juego en clave espiritual.

Así las cosas, Uno entre mil propone un tipo de ciudadano diferente, un agente dotado de autonomía para cuidar de sus intereses sin olvidar que estos se ubican junto a otros, y que para realizarlos necesita actuar, construir, nombrar y cooperar con otros. Es una apuesta por potenciar la autonomía, pero una que apela a la creación como motor principal, y para crear hay que desear, hay que disfrutar. La posibilidad de creación de entornos y realidades surge en la creatividad y esta a su vez es producto del disfrute, de la pasión. Para Uno entre mil jugar es sinónimo de despertar, de avivar, de excitar, de hechizar. Estas palabras describen perfectamente el papel del juego en este grupo, porque es un movimiento que anima a la acción, en el sentido de crear una realidad acorde a lo que cada uno desea experimentar, y esta es una conciencia de gestión que implica reconocimiento del otro, de sus diferencias, valores y saberes. Ese reconocimiento es una apuesta a la construcción colectiva sin pretensiones universalistas; por el contrario, es un aporte voluntario de un grupo de personas conscientes de su capacidad de acción y transformación 
social, de su aporte individual y colectivo a un tejido social como el de Medellín, tan diverso y complejo.

Es comprender que lo público no es una externalidad del sujeto, sino un ámbito que lo determina, y este a su vez puede afectarlo "positivamente" si así lo decide; es una cuestión de decisión que implica intención y acción. La posibilidad de aparición en lo público no es secundaria, sino que es parte del entramado que constituye lo privado, y dotar de disfrute y alegría el entorno inmediato que existe entre lo público y lo privado es tal vez el aporte más significativo de este grupo de jóvenes, que entienden que solo reencantando el presente con recursos mágicos como los que este grupo ha construido es posible pensar en acción colectiva orientada al rescate de los vínculos que nos hacen humanos, como el respeto, la solidaridad, el compartir y el disfrute.

Parte de los aprendizajes que se han venido configurando en el grupo tienen que ver con el ejercicio permanente de ser consciente y el despertar de cada uno de los integrantes, que está ligado con el desechar la duda, de actuar en consecuencia con el pensamiento, de soltarse de las ataduras que la mente o la sociedad imponen. En el recorrido de cuatro años de trabajo de Uno entre mil —de intentar, caminar, crear y poner en práctica eso que han construido como grupo-, han surgido muchos momentos, transformaciones y saberes construidos colectivamente en la práctica. Por ejemplo, es evidente que la organización se mueve porque cada uno de los participantes tiene un propósito personal vinculado al grupo, porque vibra con ese propósito y este ha sido interiorizado en su vida.

Esta posibilidad de articular propósitos toma forma en la palabra como creadora de universos, de realidades; así que, para los participantes el poder de la palabra es fundamental en la generación de lazos o vínculos. De esta, la palabra es fruto de la coherencia entre los propósitos que se siembran en las actividades y las acciones colectivas o las determinaciones que cada participante asume para su vida, pero también para la organización. Esto fortalece, además, los vínculos de confianza, de amistad y cercanía que se nutren con el juego.

Hay otra cosa que se ve en Uno entre mil que es reconocer al otro como la familia, como el hermano, que eso es muy frecuente $[\ldots]$ 
aquí no solamente o lo más importante no es hacer actividades, porque actividades hace mucha gente, aquí lo primero es que fortalezcamos nuestros lazos y sepamos quién es el otro, cuando ya sabemos quién es el otro podemos hacer lo que sea, entonces estamos aprendiendo a eso. (Julián y Natalia, 30 de marzo de 2014, entrevistados por Molina, I., Medellín)

Este tipo de expectativas también se conectan con trabajos con los niños y niñas de la Eskuela de Artes y Ocupaciones Felicitarias, los cuales permitan un tejido más articulado en función del juego y de la forma particular de ver la vida desde la perspectiva del grupo:

Me imagino la Eskuela de Artes como un semillero de niños y niñas que nosotros no vamos a ver cada 8 días, sino que estamos en un acompañamiento constante, que ya no están dentro de ese sistema, sino que ya estamos creciendo con ellos en comunidad, entonces es pensarlo para la vida, no para el momento, para una aparición sino que sea una construcción diaria. (Julián y Natalia, 30 de marzo de 2014, entrevistados por Molina, I., Medellín)

De lo anterior se puede entender un poco más claro cuáles son las formas a partir de las cuales Uno entre mil argumenta su práctica y el despliegue de lo político en su acción. Se habla de una escuela, de un espacio diferente a la institución educativa, un espacio que evoca un tipo de sujeto diferente, que aprende haciendo, jugando, disfrutando de lo cercano, del territorio, que se constituye en comunidad de sentido a través de las ritometodologías del grupo. No se alude a niñas y niños con más saberes o conocimientos, sino a agentes conscientes de su entorno, de ellos mismos y especialmente, de sus talentos, de las capacidades propias que se cultivan colectivamente, en una perspectiva intergeneracional a través del tiempo, como un proceso compartido de aprendizaje y diversión, que sitúa al juego como corazón de la práctica.

Esta apuesta contendida en la Eskuela de Artes y Ocupaciones Felicitarias ubica a la experiencia lúdica como forma de saber que produce reflexión y acción para la vida de unos agentes específicos, es un proceso de largo alcance que se alimenta de lo cotidiano y que 
perdura en el tiempo, que apela al despliegue de experiencias que afectan y despliegan los sentidos como fuente de aprendizaje individual y colectivo, con el ánimo de potenciar a un agente que privilegia una razón sensible consciente de su potencial y de su papel en una sociedad situada histórica y territorialmente.

Así las cosas, el trabajo de Uno entre mil no se limita a crear espacios para el juego, sino a hacer del juego un instrumento consciente de acción que potencia la creatividad para construir otras formas de acción política que tienen impacto no solo en lo colectivo, sino también en el campo que le corresponde a cada participante, a uno mismo.

\section{Corporación Pasolini en Medellín: lecturas emocionales desde la expresión}

Pasolini en Medellín nació en 2004, a partir de un trabajo de investigación de dos estudiantes de antropología de la UDEA. La idea original incorporó el pensamiento o perspectiva de Pier Paolo Pasolini (19221975) a la etnografía audiovisual, a partir de la aplicación de talleres con jóvenes de la periferia de Medellín, donde se buscó generar nuevas formas de narrar-se, a partir del uso de lo audiovisual.

El grupo que se conformó en ese momento empezó a adelantar procesos audiovisuales individuales y algunos colectivos, con financiación de diferentes entidades, sobre temáticas asociadas a violencia y territorio, y memoria colectiva.

En este tiempo, el trabajo con jóvenes se mantuvo, especialmente con aquellos que utilizan al hip-hop como su forma particular de expresión. Así nació Ojos de asfalto (2008-2009), uno de los proyectos famosos de la corporación. En este proceso se fortaleció la metodología propia y se establecieron relaciones que se mantienen hasta hoy con organizaciones sociales; además, sirvió para delimitar la intencionalidad de la Corporación Pasolini en Medellín. De igual manera, se inauguró un trabajo intergeneracional que fue develando más historias en los barrios populares de la ciudad, historias que evidencian "cómo hay juegos de violencia que encarnan lo cotidiano", y en las cuales hay una riqueza de historias, de aprendizajes y de reflexiones en torno al 
ser joven, al pertenecer a un barrio como El popular y a conocer las historias que se tejen en la cotidianidad del territorio.

Este tipo de procesos liderados por los pasolinis hace explícito el interés del grupo por la construcción del mensaje a partir del audiovisual, es decir, el tipo de argumentación que incorpora el grupo se produce en medio del momento de reflexión que suscita la producción audiovisual, lo que genera que sean los protagonistas o quienes viven esas historias los que descubran cómo darle voz e imágenes a esas vivencias o a esas historias silenciadas por el ruido de una sociedad sorda. La producción audiovisual se nutre de sentido cuando es la conversación, la investigación y la reflexión los elementos que anudan las historias particulares que dan cuenta de la vida en los sectores populares de Medellín.

Para la corporación, la potencia de sus relatos o de los productos audiovisuales que se han generado a lo largo de su historia se condensa en la experiencia de lo cotidiano como insumo inagotable para configurar mundos de significación.

Lo cotidiano, coger lo que pasa en el día a día, desde la experiencia y de lo cotidiano creo que surge la verdadera magia, porque él [Germán] nos decía algo cuando lo conocimos que se me quedó grabado, cuando uno quería contar una historia o narrar algo, uno siempre buscaba como la idea genial, y muchas veces no, la idea genial de súper película con los súper efectos pues no, pero desde lo cotidiano pueden surgir las historias más bonitas, y desde ahí busca mucho pasolini, desde lo cotidiano. La credibilidad que le da al cine lo cotidiano, la magia y lo bonito, la fuerza que le da lo cotidiano al cine me parece genial y eso es lo que creo busca mucho pasolini. (Germán y Wicho, 24 de marzo de 2014, entrevistados por Molina, I., Medellín)

Esta es también una lógica antagónica en relación con los contenidos hegemónicos que circulan por vías tradicionales sobre la ciudad. En tanto, con estas historias se busca hacer evidente la magia de lo local, lo cotidiano, sin endiosarlo ni con otra pretensión más que mostrar la realidad como es, sin intermediarios y desde las significaciones de 
sus protagonistas, sin acudir a relatos fantásticos o grandes aventuras épicas. La complejidad y contradicción de las historias locales vividas por los habitantes de los barrios de las comunas de Medellín muestran otra realidad, otra forma de nombrar y de resignificar la vida en sociedad, la violencia, la injusticia, la historia, el deber ser y las oportunidades de subsistencia de quienes viven otras realidades.

Uno de los temas fuertes que se pueden identificar en la producción de la Corporación Pasolini en Medellín es sobre la memoria, dado que en el contexto de justicia transicional esto es muy importante para el momento presente, a partir de los altos índices de violencia que vivió y vive la ciudad. Esta reflexión audiovisual en torno a la memoria no siempre está asociada únicamente a la violencia, sino también, y sobre todo, a la memoria colectiva, a la memoria de barrio. Sin embargo, esto no siempre fue así, pues en sus comienzos el registro de la violencia asociada a los barrios y a los jóvenes de sectores de escasas oportunidades era una línea de producción latente. En sus orígenes, las historias que se contaban buscaban reflejar una realidad descarna$\mathrm{da}$, con el paso del tiempo. Esto se fue matizando y se procura ahora generar más complejidad en los relatos, en los protagonistas, en sus motivaciones, en sus búsquedas y descubrimientos.

El trabajo que se mantiene, y que es fruto del proceso reflexivo con las comunidades, busca desmitificar el concepto de memoria, vinculado en la mayoría de los casos únicamente a las víctimas, y explorarlo más desde las organizaciones sociales, sobre todo en función de lo colectivo, de los imaginarios en torno a problemáticas de género, de patrimonio, de los barrios y de la ciudad misma. Con lo anterior, se puede inferir que los agenciamientos discursivos que produce el grupo están orientados a la construcción de relatos propios, es decir, con rostros e historias reales, que desmitifican algunas ideas preconcebidas, por ejemplo, sobre los jóvenes, y que apelan a resaltar otras posibilidades de existencia, a construir otros imaginarios sobre la condición juvenil y sus complejas manifestaciones sociales.

Una característica de la producción de los pasolinis es la pretensión de que las piezas o películas perduren, que el simbolismo y las representaciones que trasmitan no pierdan vigencia con el tiempo, que el mensaje perdure con los años y que se mantengan actuales; es decir, 
que den cuenta de una realidad que es un continuo y que perdura en el presente.

Se puede inferir además que esta intencionalidad es una metáfora que da cuenta de su proceso, pues es darle una forma presente a una cara de la realidad, por ejemplo, de un sector, de un momento específico que, a pesar del tiempo, sigue expresando contenidos válidos para comprender subjetividades y prácticas específicas. Asimismo, el hecho de que los pasolinis asuman cada corto como una película, es en sí mismo una metáfora, pues en cada producto se busca que esa secuencia de imágenes sea completa, es decir, que exprese una versión compleja de la realidad, que se asuma como una pieza por sí misma valiosa, ya que captura en determinado tiempo una historia que sirve como elemento de discusión que permanece en el tiempo y que cuenta una perspectiva de tantas que nutre a la sociedad.

Por otra parte, en la forma como se negocian los intereses en cuanto a la producción, se evidencia un alto nivel de autonomía en lo que se hace; lo que quiere decir que cada participante pone en juego su criterio cuando hace parte o dirige un proyecto, es decir, prevalece un criterio de autor y aunque son evidentes las diversas formas o posibilidades de contar las historias, se comparte un gusto o intencionalidad porque las narrativas sean más complejas, en el sentido de exaltar la forma como se cuentan las cosas, apelando a una estética audiovisual que privilegie a la metáfora como una posibilidad amplia de transmitir ideas, relatos y vivencias, que no sobrepase al relato y su profundidad, pero que equilibre contenido y forma.

Esto se logra en la medida en que en la corporación se puedan hacer proyectos colectivos e individuales, en los cuales es posible experimentar por parte de los interesados aspectos que atañen a la producción audiovisual, a los formatos, a las narrativas, en fin, a las búsquedas audiovisuales que permiten la innovación en cada proceso.

Sin embargo, esta preocupación sobre el cómo no riñe con la intención de procurar la evolución en la construcción de los mensajes, es decir, la búsqueda permanente por ampliar la mirada, sin exaltar únicamente lo bello, sino de advertir la complejidad de la vida en el barrio, permeada de violencia y tranquilidad; en fin, de dar cuenta de las ambigüedades que nutren lo cotidiano. 
Este es uno de los vínculos interesantes que produce el grupo, en función de articular la investigación desde una perspectiva de las ciencias sociales (antropología, comunicación y sociología) a partir del uso de metodologías de estos campos en el proceso de producción, y la búsqueda estética al momento de materializar un relato, es decir, de hacerlo bien, interesante o innovador en términos audiovisuales, y vincularlo además a un proceso de construcción de sentido entre los participantes. Es decir, las historias que producen articulan estos elementos, lo cual las hace doblemente interesantes, pues subyace en cada una un proceso investigativo y participativo que le confiere a cada película un valor adicional.

Una de las banderas de la corporación es la reafirmación-creación del método pasolini, su estrategia metodológica de producción colectiva de relatos audiovisuales. Esta es una innovación que hace al grupo acreedor de reconocimiento en diferentes espacios académicos. Lo anterior tiene que ver con el trabajo que hacen cuando asisten a las diferentes comunidades, porque buscan a partir de talleres construir formas de narración que articulan la perspectiva de los protagonistas y sus propias historias de vida; esto se ha logrado con diferentes grupos sociales, incluso en procesos intergeneracionales sobre narrativas de hip-hop, memoria y sexualidad.

La apuesta de formación es de transferencia, siendo conscientes incluso de que esta última nunca es real del todo, solo cuando los grupos tienen la tecnología y los recursos instalados; ahí sí se puede hablar de una transferencia total. Esto se configura a partir de un ejercicio de diálogo y negociación permanente entre los participantes y los talleristas, quienes en equipo van configurando las propuestas narrativas, los formatos y el ejercicio de producción.

De ahí que este ejercicio permanente de construcción colectiva sea una de las estrategias de enunciación y argumentación que ha incorporado el grupo como metodología de trabajo, a través de lo que han denominado "el audiovisual colaborativo", el cual busca que los protagonistas de un territorio específico narren su propia historia, apelando a la ficción o al documental, para contar-se, para reelaborar la experiencia con una intencionalidad transformativa. 
El registro sin más de la vida cotidiana no nos permite entender muchas cosas, de lo que somos culturalmente, la ficción entra en el espacio del deseo, entra en el espacio de la proyección de lo que queremos ser, pero también entra en el espacio de la elaboración de la experiencia y entra en el espacio de la reconfiguración de una posibilidad de transgresión de la realidad misma, es decir, el sujeto pareciera atado a sus condiciones estructurales y sociales, la ficción le permite volar sobre eso, y tumbar de pronto algunas taras, y creemos que ese es el espacio de la ficción no de lo real, pero vía de la ficción puede haber una transformación de lo social. (Arango, 2015, entrevistado por la Corporación Memoria y Saber Popular $)^{6}$

Para los pasolinis, lo audiovisual brinda la posibilidad de pensar etnográficamente; esta fue la intuición inicial con la que empezaron este camino, en la búsqueda por construir relatos audiovisuales "otros" sobre la vida cotidiana, como una posibilidad de configurar experiencias que les permitieran a los participantes salirse de ellos mismos para observar el mundo alrededor, es decir, configurar nuevos lugares —en sus palabras- desde los cuales pensar-se el barrio o la ciudad. Es afinar la mirada, reconfigurar mundos sensibles de expresión que antes no existían, como ejercicio reflexivo de autoobservación y de nombrar las cosas desde otro lugar de enunciación. Creo que es acá donde logran generar cruces o relaciones que antes no existían para los participantes, es decir, crear relaciones que antes no eran explícitas entre ámbitos diversos y producir nuevos sentidos frente al relato, pero también frente a cada participante y el entorno donde opera.

Mezcla la labor de la etnografía con el cine, porque pensar etnográficamente es como si fueras a hacer una película, y lo otro es que es una experiencia deductiva, a partir de ejercicios continuos de observación y sensibilización, entonces como que ese aprendizaje

6 La entrevista completa puede consultarse en: http://www.saberpopular.org/ audios $/ 52 \% 20$ Programa $\% 20 \mathrm{La} \% 20$ Corporacion $\% 20$ Pasolini $\% 20 \mathrm{y} \% 20 \mathrm{el} \% 20$ Audiovisual\%20Colaborativo\%20-Ciencia\%20Pa\%20La\%20Gente.mp3 
del cine no pasa en primera instancia como este es un plano general, este es un guion, sino que primero es cómo ve usted, cómo es su experiencia visual, cómo es su experiencia narrativa, entonces si nos encontramos en la experiencia de la vida normal lo que es lo dramático, qué es un conflicto, cómo se ve esa historia en tres actos, pero primero es cómo la cuento yo, cuáles son mis maneras de narrar, así como con el montaje, no se aprende de edición en el computador, no se aprende pensando así se hace un corte, cuál es el montaje, sino primero, para entenderlo cuéntame una experiencia fugaz en tu vida. (Germán y Wicho, 24 de marzo de 2014, entrevistados por Molina, I., Medellín)

Así, el producto audiovisual es el mensaje, o sea, la imagen como producto con sentido, como signo y símbolo que encierra un significado complejo, pero que existe gracias a un proceso reflexivo y creativo que se hace colectivamente, a partir de realidades concretas, no se inventa de la nada. "Siempre se hace investigación por el acercamiento que se tiene con la gente, pero ha habido otros procesos que han sido más argumental, más ficción, también hay un trabajo de campo ahí” (María, 28 de marzo de 2014, entrevistada por Molina, I., Medellín).

De ahí que en las películas predomine sobre todo el lenguaje de las acciones, sin tanto diálogo, pues la imagen misma da cuenta de lo que pasa, fruto también de una tradición oral que se mantiene y que refuerza esta forma particular de contar las cosas o de nombrar haciendo. Asimismo, se han incorporado propuestas audiovisuales que amplían la mirada, como la animación o las fotonarrativas; son otras modalidades de narración que les permiten a los pasolinis explorar oportunidades de creación e innovación en torno a la producción audiovisual, adscritos a procesos específicos.

Camilo hizo uno con unos niños en Sonsón, la Quinceañera, y era para hablar de violación, y como el tema era pesado, usaron la estrategia de la animación, y como lo tenía que narrar un niño, y no se podía actuando pues esa animación funcionó perfecto. Series de fotos también hemos hecho, yo vengo también de México con el rollo, no lo hemos podido echar pero es lo de fotonarrativa, 
es también cortos pero solo con fotos y es narración. (Germán y Wicho, 24 de marzo de 2014, entrevistados por Molina, I., Medellín)

Esta búsqueda de relatos y narraciones propias tiene implícita una intencionalidad de activar subjetividades políticas, de sensibilizar y reconocer el tipo de prácticas e imaginarios que habitan lo cotidiano, de reelaborar la experiencia y activar la potencia de los agentes y de los grupos con los que trabajan. Este es el tipo de cadenas de significantes que se construyen colectivamente en la producción audiovisual.

Cuando el proyecto empezó, la intención era dar voz a aquellos que habitaban los barrios de la periferia y que eran segregados, pues la ciudad siempre se pensó del centro hacia las periferias; esto fue lo primero que se quiso explorar con los apuntes para una etnografía visual.

Cuando empieza la Corporación el proyecto se llamaba apuntes para una etnografía visual sobre la periferia urbana, lo que pensábamos ahí era en la segregación, y primero un factor para pensarse la violencia de la ciudad era la segregación, ¿qué queríamos en ese primer bloque de Pasolini? pensar en los barrios que estaban alrededor de la ciudad y que no hablaban por ellos mismos, sino que de alguna manera habían sido construidos desde el centro. (Corporación Pasolini en Medellín, 15 de marzo de 2014, entrevistados por Molina, I., Medellín)

Posteriormente, se replicó la idea con jóvenes de otro sector de la ciudad, con la metodología más afinada, enfocados más a un proceso de formación con jóvenes de barrios populares. Desde ese momento, se pensó en contribuir a las organizaciones de base para fortalecer más líderes juveniles, "nuevos dinamizadores"; así, con el trabajo de la corporación se han fortalecido a la vez otros grupos, especialmente de hiphop. La formación siempre va más allá de lo audiovisual y se configura en la exploración de otras posibilidades de reflexión y de narración de la vida en estos sectores, es decir, crear otras cadenas de significación vinculadas al barrio, al ser joven y al arte como manifestación política.

Luego llegan dos proyectos en paralelo que es con el Icanh que es ojos de asfalto, con hoppers de la ciudad con Ana y yo a la cabeza, 
y otro con Duván, Camilo y los amigos del Iner y es sobre memoria de violencia, pasamos entonces del asunto de la segregación con el hip hop a la construcción del mensaje y ya no es... primero nosotros queremos contar los barrios como son, que la gente del barrio cuente el barrio como es, desde la vivencia de ellos y en este ya en el hip-hop hay ya un asunto de cómo leen ellos la ciudad, y leen temas específicos. Ahí aparece Juan Pepito que es una visión irónica de ser pillo en el barrio. Juan Pepito son muchos y son los chicos que de pelaos son jíbaros, expendedores de droga y luego se vuelven "traquetos", y es una historia muy común a todos los barrios, estos chicos lo cuentan pero a manera de chiste, y nos interesa mucho el combo, entonces lo muestran ahí. Luego está 31 de mayo, sobre un asunto de un deslave que hay en la comuna trece porque los chicos deciden que no quieren contar más la violencia ni quieren hablar más de operación Orión y Mariscal. Es un asunto de una tragedia natural que hubo ahí; otros chicos del Popular quieren hablar de la subjetividad y se van a abrir otros espacios hacia las subjetividades que son otro rollo y entonces ahí aparece la historia del mensaje y con el tema de la memoria y la violencia aparece la excusa para pensar el tema intergeneracional; entonces lo bonito del trabajo de memoria que se hizo en el Popular, era que eran señoras adultas mayores y muchachos, y todos conversando sobre el relato que ellas querían contar y las historias que cuentan, así un combo cuenta historias y este lo llevan a imágenes y ahí arman el relato. Ahí hay historias de cómo se funda el barrio, cómo pelean contra la centralidad, contra los policías para hacer sus invasiones, para fundar sus barrios, cómo hay juegos de violencia que encarnan lo cotidiano. Hay una historia muy bonita que es la de la graba que es una historia de una mujer que a la mamá la matan unos sicarios novatos por robarle una grabadora, en un lugar de culto evangélico, entonces son historias que van llevándonos a una reflexión más profunda. (Corporación Pasolini en Medellín, 15 de marzo de 2014, entrevistados por Molina, I., Medellín) 
Con esto, la corporación ha mantenido presente un interés por deconstruir el imaginario de ser joven, de aquel que vive en los límites de la ciudad, es decir, de las periferias. Los ejercicios de reflexión en torno a la memoria de cómo se construyó el barrio, cuáles fueron las luchas sociales que se produjeron y cómo configuran las prácticas sociales que los caracterizan, se dan como un interés por profundizar en el saber que reside en los habitantes y en el territorio como agente dinamizador de relaciones o vínculos sociales. Comprender el territorio desde su complejidad de relaciones es configurar relatos propios de los sectores donde se trabajó y al mismo tiempo posibilitar la reconstrucción de significaciones inéditas ubicadas espacio-temporalmente, que reconoce y ubica identidades, formas particulares de existir, de entender la ciudad y la sociedad. El video se convierte en una ventana a estas realidades ocultas o estigmatizadas.

Con esto se visibilizan otros lenguajes, otras estéticas, otras formas de argumentar y de entender la realidad, las intencionalidades o motivaciones presentes en un espacio compartido como el barrio o la comuna. Comprender otras formas de acción social desde el margen o desde los excluidos es vital para articularlo a un discurso legal de ciudad que prioriza políticas para este tipo de población, en muchas ocasiones sin entender a profundidad los matices de estas comunidades. En Medellín, el trabajo con jóvenes se ha nutrido de experiencias similares, así que se han hecho muchas cosas desde la institucionalidad y también desde las propias comunidades.

Acá hay muchas cosas para hacer, pero se están haciendo, como que no ha cesado esa acción juvenil ahí, alguna politizada y otra no, pero en todo caso siempre hay colectivos haciendo cosas, nosotros en un principio también empezamos a trabajar con jóvenes pero contando sus historias y que la gente pudiera contar, que hubiera narraciones distintas, y yo creo que eso se ha logrado. (María, 28 de marzo de 2014, entrevistada por Molina, I., Medellín)

Pero ese interés se fusionó también con las apuestas individuales de aquellos que han ido participando en la corporación con búsquedas personales, como por ejemplo pensar o divulgar la investigación desde 
la riqueza del lenguaje audiovisual, más desde la intuición que desde teorías específicas; así se han ido articulando intereses particulares en torno a una intencionalidad más política y social que se hace explícita en el trabajo de la Corporación Pasolini en Medellín.

De esta manera, el grupo busca una demarcación de la acción de otras organizaciones gubernamentales o privadas, atendiendo especialmente a la generación de vínculos entre los participantes de los talleres, a formar procesos de investigación y de apropiación a partir de la construcción del audiovisual. Esto genera unas posibilidades de reflexividad que animan a la construcción de significaciones propias en torno a lo cotidiano y a la apropiación territorial, y de esta manera se activan espacios, discusiones y construcciones de acciones u otros sentidos en torno a lo público.

Nos interesa cómo ese asunto de lo cultural se mueve en lo cotidiano, cómo se da en cada acción y práctica cotidiana. Y ya lo audiovisual sería como comprender esa cotidianidad con fines de un análisis cultural pero a través de imágenes, bien sea de que yo registre que es la manera más insípida de la etnografía visual, o bien sea que yo a través de la imagen establezca una relación con el otro, establezca una relación e interacción con el otro y eso para nosotros es lo más importante, esa mediación que creamos con el sujeto a través de que hagamos una foto, de que hagamos un video, de que hagamos dibujos [...] El registro es una versión de la realidad, en el registro siempre hay alguien detrás de la cámara y esa perspectiva reflexiva es la más interesante, más de vanguardia de la antropología visual y por ahí nos metimos nosotros. Las imágenes hablan más de quien las ejecuta que de lo que está mostrando realmente la foto, ese es como un principio ahí. (Corporación Memoria y Saber Popular, s. f., s. p.)

Descubrir otros lenguajes al narrar y otros saberes pasa por el ejercicio de activar en los agentes implicados una reflexividad sobre su cotidianidad, sobre su entorno y sus percepciones, favorece entre los participantes la potencia del mostrarse, de confrontarse y ubicarse en una realidad específica que nombra y produce unas subjetividades 
que modulan su existencia. Este ejercicio es una apertura de lo político que se encuentra en cada uno de los procesos que adelanta la corporación y que es parte fundamental de la metodología participativa que ha consolidado, y que en algunos casos desemboca en procesos de acción colectiva enfocados a la expresión y visibilización de agentes como los jóvenes.

De esta forma, se puede identificar una preocupación por la formación audiovisual con un sentido investigativo, fomentando otros lugares de enunciación y alimentando la intención permanente de innovar y crear así formatos e historias inéditas que se ocupen de mostrar otras realidades, otros agentes y sus percepciones en torno a lo social, a lo colectivo, a sus intereses y a la vida misma.

En cuanto al proceso de creación, se destaca la "cocina de guiones", como estrategia que los pasolinis han establecido para construir colectivamente las propuestas audiovisuales que se presentan a las convocatorias o los procesos que se adelantan en la corporación. La cocina, como su nombre lo indica, es el ejercicio literal de cocinar alimentos e ideas, de combinar sabores y saberes. En el proceso se van generando ideas, se muestran avances de lo que existe hasta el momento, se configura un sentido colectivo frente a lo que se hace, se generan compromisos o acuerdos a nivel individual y por grupos con tiempos delimitados; pero también se come, se comparte como grupo y se conversa de lo cotidiano, de la vida o de los amigos que hacen parte de Pasolini.

Está la cocina de guion como la herramienta principal, y a veces no llegan solo proyectos audiovisuales sino también de formación, organicémonos, quién puede, quién se le mide... muchas veces la presentamos en grupo, pan, cada uno bota su idea, y hay trabajo individual y trabajo por grupos, y por calendarios también, o por convocatorias, hay que aprovechar. (Germán y Wicho, 24 de marzo de 2014, entrevistados por Molina, I., Medellín)

La cocina de guiones es ante todo un espacio de conversación sobre lo que pasa con los procesos que están vigentes, de lo que pasó en la ciudad, de lo nuevo que leyó o encontró alguien, del cine, de la vida 
en Medellín y de la corporación. Es entonces una manifestación concreta de esa forma de argumentación y de enunciación que ha consolidado el grupo; es ante todo un proceso de encuentro, de conversación, de acción, en el cual se integran saberes y sabores específicos que van produciendo una forma particular de entender la práctica y construir conocimiento sobre la acción. Esta forma de encuentro posibilita el ejercicio de planeación o proyección, tanto del grupo, como de los procesos vigentes, de propuestas y alianzas en las que se participará. Es un diálogo permanente entre los participantes y los nuevos aliados, es un espacio de construcción de identidad.

Con esto, el grupo entiende que parte del éxito de su trabajo durante estos años es un ejercicio de autonomía a partir del interés colectivo por la creación audiovisual; es una apuesta por configurar saber y narraciones propias desde la experiencia de lo popular, de lo alternativo, de lo excluido, para que se incorpore en el imaginario de ciudad, para que se hagan visibles otras prácticas territoriales y culturales que amplían la noción de ser joven, de pertenecer a ciertos sectores de la ciudad y complejizar así el ámbito de lo común.

De esta manera, la Corporación Pasolini en Medellín va configurando a partir de su apuesta audiovisual mundos de disentimiento y argumentación desde la comprensión y visibilización de lo cotidiano, a partir de la exploración reflexiva de los entornos donde se produce lo común, lo social, el "parche"; es decir, desde el corazón mismo de las prácticas culturales, y esto las amplía o las representa en una constelación de sentidos, de actores, de ritmos e historias que son las que se materializan en los cortos, en los documentales, en los argumentales y en los videos musicales. En más de los setenta productos que han ido produciendo a lo largo de estos años, la corporación ha explorado historias aparentemente "pequeñas", que han contribuido a la reconstrucción de la memoria histórica y colectiva de los barrios, de las disputas territoriales recientes en las comunas de Medellín, así como a mostrar o profundizar en las identidades construidas en estos sectores, en las prácticas culturales y en los imaginarios que habitan y acompañan a sus moradores; así se construyen con los protagonistas de estos relatos los matices que los designan, ubican o excluyen del entramado social. 
La Corporación Pasolini en Medellín tiene una apuesta estética enfocada a "unas lecturas emocionales desde la expresión”, por eso apelan a una sensibilidad implícita en los relatos que atraviesa toda la producción y que no se limita únicamente a la marginalidad, o a lo urbano, sino que da cuenta de los diversos intereses de cada uno de los realizadores. Así que existe gran variedad de material que refleja intenciones, momentos, poblaciones y procesos, diferentes cada uno, pero que buscan ante todo que los sujetos implicados narren su historia, su realidad, y que a partir de ese aspecto narrativo se pueda generar una reflexión que permita una posible transformación de la realidad expuesta.

Estamos parados en la expresión, confiamos en que los sujetos puedan elaborar su historia de una forma que salten de esa realidad que les ha tocado, y en eso pecamos a veces de ilusos, como dice Duván, hay unas condiciones materiales, físicas en las que los pelaos están, pero nosotros tenemos confianza en la expresión, y confiamos en que esos patrones de expresión están dados en que este personaje puede contar y puede narrar, para nosotros es muy importante que el sujeto narre para nosotros lo más básico es que la narración puede darnos el salto, con César por ejemplo hemos dado la discusión de que porque hay tanto rap en el parche en Pasolini, es porque es uno de los géneros musicales que más está en el asunto de la narración, de narrar la ciudad y mover ciudad, y como que nuestra tabla de salvación es pensar la narración como un factor de protección y la posibilidad que estos muchachos elaboren. (Corporación Pasolini en Medellín, 15 de marzo de 2014, entrevistados por Molina, I., Medellín)

Por eso el lema de la corporación es desarmar mentes; también se propone la cámara como una herramienta para contar, de ahí la narración como posibilidad de ampliación del mundo de quien narra y a quien narra.

También se ha generado como una cosa de autor [...] tienen la narrativa de cada quien, pero sí comparten un gusto por la literatura, 
por las metáforas, por las narraciones que no necesariamente sean explícitas, que sean cosas estéticas, pero que también cuenten algo, que cuenten algo sobre la cotidianidad, sobre la realidad, sobre las vivencias, como relatos muy cotidianos, y yo creo que sigue estando, pero cada vez como se va aprendiendo más entonces también se va queriendo hacer cosas más como formar primero, que haya más nivel en todos los sentidos, eso tiene sus cosas buenas y malas, porque también en lo otro se privilegiaban los relatos en sí mismos, y ahora digamos que también hay un privilegio de la forma que ojalá no sobrepase el contenido, que es lo importante. Por eso es que cuidamos la investigación y queremos que persista. (Germán y Wicho, 24 de marzo de 2014, entrevistados por Molina, I., Medellín)

De esta manera, lo audiovisual como metáfora se convierte en un modo de creación que enaltece la realidad, que permite ampliar la experiencia de lo cotidiano, de la vida de los barrios, de los jóvenes o de los protagonistas de estas historias; que deja comprender más allá de la cotidianidad de la ciudad, es una potencia que muestra otros actores, otras experiencias, otras significaciones. Asimismo, permite hacer visibles otros ámbitos de lo sensible que hacen parte de la ciudad y que normalmente no se perciben como tal, pero que están presentes permanentemente en el lenguaje oral, en las historias básicas o las pequeñas historias que configuran el barrio, la cuadra, el "parche", lo popular.

La metáfora se convierte entonces en un dispositivo de significación que produce saber sobre la realidad analizada y representada en el audiovisual, que visibiliza entornos y agentes específicos a partir de los cuales se configura un imaginario de la ciudad, de los lazos sociales, del tipo de prácticas culturales que edifica lo común, que evidencia problemáticas sociales de una complejidad que apenas se delinea y que interpela a los realizadores y al público que la observa finalmente. La cámara es también un recurso de posibilidades infinitas que se convierte en productor de imágenes, en un testigo de los matices de lo real, que para los pasolinis es un recurso eficaz al momento de desarmar mentes.

Esta exploración audiovisual se logra en la medida en que no todos los productos audiovisuales de la corporación son fruto de un trabajo 
colectivo, sino que también se alimentan de la posibilidad de apertura de espacios que posibilitan la creación individual, la exploración de intuiciones propias, que son clave para el proceso colectivo.

En lo narrativo hay un montón de cosas por ejemplo para mí, que yo me críe con historias del barrio, esas historias pequeñas me llamaban mucho la atención y las narraciones de los primos, como ese trabajo muy rico que hay en el barrio de lo oral, uno se narra en el barrio, yo tengo unos primos que tenían muchos sonidos: entonces que tan, que tin tan, y cogemos y pum... y a mi esas cosas me gustan, cojo esas maneras y armo el relato, como van y vuelven, van a la mitad y luego vuelven, como que esas cosas, todavía son embriones. Una cosa que me gusta es que sí creemos en el trabajo colectivo, pero también nos pillamos en un tiempo que llevábamos un montón de producciones colectivas pero también había unas preguntas personales, y bueno también hemos dado chance como bueno, paremos un poquito, como esa cosa muy comunitaria, y vamos a hacer películas cada uno, que beben finalmente también de ahí, y que también quiere llegar a ese público, llegar a esas personas [...] (Germán y Wicho, 24 de marzo de 2014, entrevistados por Molina, I., Medellín)

Con esta apuesta estética, se hace explícita la reivindicación de las historias mínimas, por denominarlas de alguna manera, de lo cercano, lo aparentemente trivial, lo cotidiano, capturándolo y potenciándolo a través de la narración, otorgándoles amplitud de sentido, pues estas se convierten en piezas que promueven la reflexión, que hacen aperturas de significaciones, que exaltan una versión, pero amplían los límites de la enunciación, provocan otros ámbitos del decir, del hacer y le dan presencia e imagen a lo cotidiano, le dan trascendencia e inmortalizan un momento específico del proceso y de la realidad.

Normalmente las películas se preguntan por quiénes somos, cómo nos relacionamos, esas que son preguntas antropológicamente muy interesantes. Pero si tú vas a registrar con una cámara el deseo, el deseo no está ahí, el deseo no es evidente, es como un poco la 
mentira que tenemos de que el registro lo puede todo. Pues si vas a ir a ver gente que desea muchas cosas, pero yo te estoy registrando a ti en unas imágenes, veo tu rostro, pero ¿qué me puede decir ese rostro o qué me pueden decir tus acciones de lo que deseas?..., quizás nada. Entonces hay un intento de atrapar lo invisible, y ¿cómo se hace eso?, a través de la ficción. Entonces ahí hay la impronta y es una cosa que hemos seguido nosotros. Nosotros ficcionamos..., la ficción es una necesidad cultural, la ficción es por un lado la elaboración, construir narraciones de lo que hacemos, construir narraciones de lo que nos acontece. El trauma es como la mejor explicación, el trauma es la no-narración porque estamos traumatizados. Entonces la ficción es la posibilidad de narrar la experiencia. Pero la ficción es también la posibilidad para nosotros como antropólogos de conocer qué hay en la cabeza de la gente, cómo son sus deseos, cuáles son sus sueños, entender cosas que de alguna manera en el tú a tú no podemos registrar. (Corporación Memoria y Saber Popular, s. f., s. p.)

Los aprendizajes construidos en el tiempo que lleva la corporación son muy diversos y se pueden entender también como características específicas de su experiencia política. En primera instancia, se puede asociar a la intuición, la importancia de hacer lo que le apasiona o le nace a cada uno. En ese atreverse se logra una amalgama de relaciones, de posibilidades de creación o de experiencias, que ante todo iluminan las prácticas y los procesos, pues cada vez se van complejizando e incorporando más conocimientos o saberes de todo tipo, que van fortaleciendo a cada participante, pero también al grupo. Este es el caso de la posibilidad creadora del lenguaje audiovisual, que excede la idea de ser solo una herramienta y se convierte en una constelación de enunciación que desborda la técnica y se alimenta de la diversidad de miradas que se articulan permanentemente en la construcción de un mensaje, de un video clip o de una historia ficcionada.

Son unos básicos que son como valores para la vida, y es que lo poco que sé lo he aprendido con la gente, todo ha sido muy empírico, pero es muy importante que yo me atreví a que mi intuición 
era entregársela a otros, y en ese tiempo como lo poco que sé lo fui introyectando ahí; y también como cada cosa nueva que hemos ido aprendiendo ahí la hemos introducido en los talleres, eso es muy importante con lo poco que sé de cine y los proyectos individuales que he hecho han bebido de eso. (Germán y Wicho, 24 de marzo de 2014, entrevistados por Molina, I., Medellín)

Así, en palabras de los protagonistas, surgen aprendizajes en relación con la importancia de aprender a negociar en la vida, de mantener la escucha activa y asumir al antagonismo como una condición del convivir, situación que exige un gran esfuerzo de todos los implicados.

El lenguaje audiovisual es todo un mundo y no solo una herramienta, una técnica; y lo que dijo Ana María en esa reunión y también me gusta mucho es que en Pasolini realmente acudimos personas de distintas procedencias, entonces también son múltiples las miradas que se juntan y en el trabajo en equipo que es muy difícil. Congeniar con tanta gente es muy difícil, entonces hay roces, hay que trabajar en equipo, colectivamente y eso se vuelve como un complique a veces y eso es también un aprendizaje. (María, 28 de marzo de 2014, entrevistada por Molina, I., Medellín)

Este es uno de los aprendizajes más significativos entre los integrantes: la amistad como la posibilidad de construir un techo común en medio de tantas diferencias, de los conflictos, de la diversidad de intereses, convocando a la confianza y al fortalecimiento de vínculos etéreos asociados a la sensibilidad, que terminan siendo inasibles, pero muy importantes en este tipo de organizaciones, pues se constituyen en el cemento del grupo.

Yo creo que es un trabajo desde lo colectivo, yo creo que he trabajado así desde chiquito y con el trabajo que hemos hecho en la Corpo hemos aprendido que es muy difícil, hemos encontrado cosas pero hay que afianzar eso de trabajar en lo colectivo, y eso en la vida es como una capacidad de escucha muy tenaz, de paciencia, de calma, es que uno es muy imponente, entonces toca estar pendiente para aprender a negociar, eso es una cosa, y también el 
aprendizaje de la amistad que es muy teso, yo también me angustio mucho y que por ejemplo estoy preocupado por esto, y me dice César no venga, esto va a salir así, y así cuando estoy como muy preocupado envolatado Ana me baja mucho, y me dice no venga tranquilo que esto sale, fresco que acá nos movemos; y como con los muchachos ya he aprendido como cosas más en detalle, más pequeñas, como de resolución de conflictos [...] (Germán y Wicho, 24 de marzo de 2014, entrevistados por Molina, I., Medellín)

Además de lo anterior, también se puede inferir que hay una serie se aprendizajes vinculados al funcionamiento eficiente de la organización, que parten de la necesidad de tecnificar la labor, de cumplir con los requerimientos de financiación, de organización, de acuerdo con el mercado o las instituciones que financian y que exigen una tecnificación en la gestión que se va configurando como un aprendizaje vital de la experiencia. Este tipo de saberes no solo se quedan en la corporación; también se van transfiriendo a las agrupaciones juveniles con las que hay relación, puesto que es un saber técnico vital para la supervivencia de estas organizaciones barriales. Así, para los grupos de jóvenes de hip-hop, este tipo de exigencias les permite formarse en elementos de gestión y formulación de proyectos, o pensar alternativas de financiación que potencien las ideas artísticas que nacen en los barrios o comunas.

Todas esas cosas de formular proyectos, de gestionar, de pensarnos lo económico, de pensar todas estas actividades entonces ya uno las replica en la escuela de hip-hop, entonces ya vamos aprendiendo que si queremos tener un proyecto serio, tenemos que estructurar una idea seria, que si queremos una financiación tenemos que buscar una financiación clara, cómo, entonces uno también va aprendiendo de cómo llevar el proceso a otra escala, entonces uno va también practicando redactando cositas, y hemos estado así, ya hemos levantado presupuesto por PP [presupuestos participativos] entonces uno va aprendiendo y se va replicando, y se va abriendo [...] y bueno la idea es que nos gusta el hip-hop, pero sabemos que vivir del arte es muy complicado 
entonces aprender métodos y mezclar y sacar ideas de cómo vivir de lo que me apasiona. También como sabemos que el hip-hop es algo que propone ciudad, que propone memoria, que busca otras alternativas de vida, y como no es muy bien visto para la sociedad entonces sabemos que para vivir como de esa ideología de lo que a uno le gusta hacer entonces hay que aprender, hay que seguir afinando cosas para uno estar donde quiere y de lo que a uno le gusta. (Germán y Wicho, 24 de marzo de 2014, entrevistados por Molina, I., Medellín)

Asimismo, se pueden encontrar aprendizajes asociados a la producción audiovisual, saberes permanentes que van tecnificando a los agentes involucrados en estos procesos, bien sea por la profesión que cada uno adelanta, o por intercambio con otras organizaciones o con algunos realizadores, por el gusto hacia el cine que tienen la mayoría de los pasolinis, o por las capacitaciones que surgen en convenios específicos. Así pues, la consolidación de aprendizajes en este sentido es permanente y se va configurando como un elemento necesario que identifica y convoca a los participantes.

Con esto, el grupo ha aprendido a construir estrategias, así como saberes específicos asociados a su práctica audiovisual, académica y social que le han permitido establecer una forma particular de comprender y sentir la sociedad, para afectar o transformar situaciones, problemáticas, comunidades e historias específicas a partir del ejercicio de autonomía y creación estética. Es decir, en estos años la Corporación Pasolini en Medellín ha entendido que ocupa un papel importante para la ciudad, pues han aprendido a negociar entre ellos para construir con otras organizaciones (académicas o gubernamentales) espacios de formación, narración y reflexión social sobre el territorio, la memoria, las prácticas culturales, los lenguajes, etc.

Así, los integrantes del grupo establecen relación entre ámbitos aparentemente distintos. Por un lado la creación audiovisual o el gusto por el cine y, por el otro, la producción colectiva de saber y memoria sobre el barrio, la comuna, el territorio. A partir de ese cruce de intereses han generado otro tipo de producción de conocimiento que tiene implicaciones no solo entre los participantes de las 
organizaciones comunitarias con las que trabajan, a partir del ejercicio de sistematización y creación de relatos que les permite reflexionar, discutir o descubrir-se a partir de sus prácticas cotidianas, sino además en ámbitos académicos, pues este tipo de estrategias metodológicas se siguen profundizando en las clases o espacios interinstitucionales donde los pasolinis participan y promueven. Pero también entre las entidades estatales locales, pues en estos procesos se consolidan grupos de base que permanecen vigentes en los barrios y con los cuales se pueden seguir construyendo procesos de formación y despliegue artístico con miras al fortalecimiento de subjetividades políticas; y finalmente entre los pasolinis, quienes mantienen vigente su interés por continuar explorando experiencias estéticas asociadas a la fotografía, el cine y el audiovisual.

Una de las expectativas de la corporación es que se consolide como una entidad que siga trabajando el tema de la memoria y que tenga sostenibilidad, para permitir así la oportunidad de seguir "enriqueciendo nuestros métodos, nuestras formas de ver el mundo a través del cine, con más métodos, más cosas, más complementos, más ideas” (Germán y Wicho, 24 de marzo de 2014, entrevistados por Molina, I., Medellín), es decir, seguir creando, innovando y fortaleciendo el tema de la formación, y de esta manera ampliar formas de expresión, posibilidades de crear y narrar la vida a través del lenguaje audiovisual.

$$
* * *
$$

Finalmente, para cerrar este capítulo, hay que decir que la experiencia estética desarrollada por estos grupos busca "ampliar el camino hacia la experiencia limítrofe”, como apunta Mier Garza, (2015), a partir de la producción de sentido en la comprensión de sí mismos y del entorno, a través de la cual es posible problematizar lo común, los límites de lo social y las identidades. De esta manera, la experiencia estética promueve un vínculo entre los agentes que la producen o la disfrutan, lo que crea potencialidad de acción, a partir de los contenidos manifiestos, que inducen a repensar o reflexionar sobre las normas vigentes, los imperativos morales asumidos colectivamente y su condición 
de obligatoriedad, junto a la regulación de las relaciones sociales, las demarcaciones identitarias y las formas de articulación social. Es decir, a repensar lo público.

Esta potencia es justamente la que se vincula con su capacidad de producir acontecimiento, de introducir en el ámbito de lo discursivo y de lo sensible una diferencia que altera los modos de percibir, pensar y actuar sobre lo instituido, específicamente sobre aquello que a cada grupo le interesa posicionar o transformar. Como vimos, cada uno tiene una intencionalidad latente, unas formas particulares de nombrar, unos repertorios de acción específicos, el uso de metáforas (el juego, el teatro, el audiovisual) a través de las cuales es posible manifestarse y con las cuales pueden aportar a la transformación de su entorno inmediato.

En las experiencias estéticas propuestas por estos jóvenes hay todo un andamiaje creativo que surge del análisis y de la reflexión de su cotidianidad, de las relaciones de fuerza que produce lo social, a partir de las cuales generan otras estructuras perceptivas, con una pretensión de intervención sutil que posibilite abrir o ampliar la discusión, y generar con otros, no solo nuevos conceptos, proyectos y afectos, sino también unas comunidades de sentido diferente, entre pares, entre vecinos, en la intersubjetividad.

Esta práctica se presenta como una característica explícita de lo político, pues la pretensión de estos agentes no es construir otras estructuras de poder, sino un flujo dinámico de crear-acción, como devenir, que se activa a partir de un discurso autónomo que produce otros hábitos, otros espacios, otros tiempos, otros lenguajes que alteran el presente, su presente; en últimas, su experiencia de vida como agentes singulares que establecen un horizonte colectivo de relaciones.

Suponer lo político por vía de la experiencia estética es suponer la creación de situaciones o experiencias que permiten alterar creativamente y relacionalmente los espacio-tiempo del presente, como una apertura permanente que hace posible actualizar lo social.

Se puede afirmar entonces que el papel de grupos como Teatro por la paz es evocar, traer al presente los recuerdos, construir memoria, es decir, llamar a los espíritus y a los muertos para que se muestren, para que intervengan en la construcción de un Tumaco diferente, para que 
participen con los vivos en la construcción de un imaginario de comunidad diferente al impuesto por el dolor y la violencia.

En el caso de Uno entre mil, la función central del grupo es despertar, avivar, animar, excitar o estimular la creatividad, como un tiempo diferente al impuesto por la realidad, a imaginar una comunidad de agentes despiertos que vibran creando, curándose y liderando procesos lúdicos que retornan a las raíces y producen una realidad diferente, alegre, consciente y solidaria.

De la Corporación Pasolini en Medellín se puede decir que, aparte de evocar, busca expandir el pensamiento, la mirada, los lenguajes, las narrativas, la diferencia y repoblar con otras perspectivas un imaginario de ciudad, de lo que significa ser joven, de otras realidades que las lógicas de las urbes contemporáneas se encargan de invisibilizar y homogenizar.

Estas son prácticas de enunciación que apelan a otro tipo de discurso, a uno mediado por el régimen de lo sensible, que pretende hacer visible esos ordenes que instituyen lo social, y así ampliar los límites que los producen, y de esta manera se generan nuevos significantes que dan sentido a la vida en colectivo, porque es ahí donde adquieren sentido las prácticas sociales, y donde se establecen las pautas de acción que producen las reglas, los acuerdos colectivos y la concepción de un nosotros. 
